\title{
GLASBENE ZVRSTI V SREDNJEM VEKU NA SLOVENSKEM
}

\author{
JURIJ SNOJ \\ Znanstvenoraziskovalni center SAZU
}

Izvleček: Pet različnih zvrsti glasbe je dokumentirano obstajalo na Slovenskem v srednjem veku: ustnoizročilna glasba v govorjenih jezikih, latinski koral, glagoljaško petje, srednjeveška polifonija in nemški minnesang. Po predstavitvi virov, njihove vsebine in po strnjenem prikazu dosedanjega vedenja se članek usmerja $v$ razpravo o perspektivah študija in raziskovanja srednjeveškega korala na Slovenskem.

Ključne besede: srednjeveška glasba, Gregorijanski koral, zgodovina glasbe na Slovenskem
Abstract: Five distinct genres of music existed in Slovenian ethnic territory during medieval times: vernacular music in oral tradition, Latin plainchant, Glagolitic chant, medieval polyphony, and German Minnesang. After presenting the sources and their contents, and summarizing what is presently known, the article discusses the prospects for future research on medieval plainchant within Slovenian ethnic territory. Keywords: medieval music, plainchant, history of music in Slovenia

\section{Uvod}

Ob razpravljanju o srednjeveški glasbi na Slovenskem je treba upoštevati dvoje osnovnih dejstev: 1. Meje, bodisi narodnostne, politične ali cerkvenoupravne, so se v srednjem veku spreminjale in večinoma niso potekale tam kot danes. 2. Na Slovenskem je v srednjem veku obstajalo več različnih glasbenih zvrsti in tako ni mogoče govoriti o srednjeveški glasbi na Slovenskem kot o eni sami stvari. Drugo od obeh navedenih dejstev je povezano s prvim, saj so bili nosilci posameznih vzrsti glasbe različne družbene skupine, ki so bile vezane na tako ali drugače določeno ozemlje.

Kot je znano, je bilo ozemlje, ki so ga v 6. stol. v dveh naselitvenih valovih v vzhodne Alpe poselili Slovani, ${ }^{1}$ različno od tistega, na katerem je tisočletje kasneje, ob izteku srednjega veka, živelo slovensko govoreče prebivalstvo. ${ }^{2}$ Kje so v srednjeveških obdobjih

1 Peter Štih in Vasko Simoniti, Na stičišču svetov. Slovenska zgodovina od prazgodovinskih kultur do konca 18. stoletja, Ljubljana, Modrijan, 2009, str. 26.

2 O slovenski narodnostni meji v srednjem veku razpravlja: Bogo Grafenauer, Nemško politično in kolonizacijsko osvajanje v zrelem fevdalizmu, Zgodovina Slovencev, Ljubljana, Cankarjeva založba, 1979, str. 155; isti, Nastanek mest in enotnega podložniškega razreda, nav. delo, str. 175-180. 
potekale narodnostne meje, kako so se spreminjale, ni vedno jasno razvidno; še zlasti zato, ker srednjeveške družbe narodnostno in jezikovno niso bile enovite. Znotraj sicer strnjenega slovanskega oz. slovenskega ozemlja so živeli tudi druge jezike govoreči ljudje. V osrednjem delu so bile to zlasti skupine nemško govorečega prebivalstva: bodisi nemški koloni, ki so jih kot podložnike naseljevali posamezni zemljiški gospodje, ${ }^{3}$ nemško govoreči meščani, svobodnjaki, ki so se naseljevali v mestih, ${ }^{4}$ ali pa nosilci fevdalne oblasti oz. uprave. ${ }^{5} \mathrm{Ob}$ tem je treba omeniti, da je bil na področjih, kjer je živelo slovensko govoreče prebivalstvo, jezik upravnih dokumentov, listin, od konca 13. stol. dalje - razen v cerkvenih zadevah - skoraj izključno nemščina. ${ }^{6}$ Nekaj podobnega je mogoče reči tudi za obalni pas. Kot je iz Rižanskega placita razvidno, da so na začetku 9. stol. v koprskem zaledju živeli Slovani, ${ }^{7}$ tako so bila obalna mesta v jedru vedno pretežno romanska. Uradni dokumenti Pirana, Izole in Kopra, mest, ki so v poznem srednjem veku pripadala Beneški republiki, so bili pisani ali v latinščini ali v italijanščini. ${ }^{8}$ Vendar se je ob razmišljanjih o nacionalnem v srednjeveških obdobjih treba izogniti proiciranju sodobnih predstav v preteklost: Srednjeveške politične tvorbe niso bile zamišljene kot nacionalne skupnosti; narodnost kogar koli je bila drugotnega pomena in prav zaradi tega so bila družbena razmerja med narodnostnimi skupinami drugačna kot v novodobnem času.

Podobno kot narodnostne so težko določljive tudi politične meje. Medtem ko je postajal obalni pas, ki je bil v 9. stol. del Frankovske države, politično vse bolj vezan na Beneško republiko, katere del je slednjič tudi postal, ${ }^{9}$ so se v jugovzodnem delu Svetega Rimskega cesarstva, kamor je spadal ostali del današnjega slovenskega ozemlja, polagoma oblikovale zgodovinske dežele: Koroška, Štajerska, Kranjska, Goriška. Proces nastajanja ter ozemeljskega razvoja teh dežel, ki je bil ozko povezan z gospodarskim in političnim delovanjem velikih srednjeveških dinastij, je bil izredno zapleten in pogosto je tudi nejasen. V poznem srednjem veku so bile imenovane dežele že del evropskega političnega zemljevida, čeprav so se njihove meje še vedno spreminjale. ${ }^{10}$

Slednjič je bilo slovensko ozemlje razdeljeno tudi v cerkvenoupravnem smislu. Vse od leta 811 pa do 18. stol. je kot meja med dvema velikima in pomembnima cerkvenima pokrajinama, oglejskim patriarhatom ter salzburško škofijo, veljala reka Drava. ${ }^{11} \mathrm{~V}$ patriarhat je torej poleg Kranjske spadal tudi del Štajerske ter del Koroške, prav tako pa tudi koprska škofija ter obalna mesta Koper, Izola in Piran. Tako znotraj salzburške škofije kot oglejskega patriarhata je bilo zaradi oddaljenosti od škofijskih središč slovensko ozemlje nadalje razdeljeno na več arhidiakonatov, katerih meje in sedeži niso vedno jasno določljivi. ${ }^{12}$ Večji poseg v cerkvenoupravno razmejitev slovenskega ozemlja je v srednjem veku

3 B. Grafenauer, nav. delo, str. 178.

4 P. Štih in V. Simoniti, nav. delo, str. 162.

5 Nav. delo, str. 151.

6 Nav. delo, str. 162.

7 Nav. delo, str. 57-58.

8 Nav. delo, str. 162.

9 Nav. delo, str. 129-131.

${ }^{10}$ Nav. delo, str. 96-132 (poglavje "Od mejnih grofij do dežel”).

${ }^{11}$ Nav. delo, str. 52.

12 Jože Mlinarič, Cerkev na Slovenskem v srednjem veku, Zgodovina cerkve na Slovenskem, ur. Metod Benedik, Celje, Mohorjeva družba, 1991, str. 66-68. 
predstavljala le ustanovitev ljubljanske škofije $\mathrm{v}$ letih 1461-1462, ki je bila iz političnih razlogov izvzeta iz oglejskega patriarhata. ${ }^{13}$ Vendar so poleg svetnih, sekularnih cerkvenih središč nastajale na slovenskem ozemlju tudi številne samostanske skupnosti. Vsaka od teh je bila podrejena vodstvu svojega reda, kar pomeni, da so bile v določenem smislu izvzete iz ozemlja obeh cerkvenih pokrajin. ${ }^{14}$ To velja še zlasti za tisto področje, ki je bilo za glasbo najbolj občutljivo, za liturgijo. Samostanski redovi so imeli svoja liturgična, s tem pa tudi svoja koralna izročila.

$\mathrm{Na}$ tako pestro in raznoliko razmejenem ozemlju je v srednjem veku obstajalo več različnih glasbenih zvrsti, ki bi jih bilo mogoče razmejiti takole:

Glasba v ustnem izročilu. S tem je mišljeno ustnoizročilno petje in igranje kot del vsakdanjega življenja isti jezik govorečih plasti prebivalstva. Sem sodi predvsem petje v slovenskem jeziku, slovenska ljudska pesem, bodisi cerkvena bodisi tista iz drugih življenjskih območij, petje, ki so ga lahko spremljala tudi glasbila; nadalje petje v nemščini (ali kakem drugem jeziku); k tej zvrsti moremo prišteti tudi instrumentalno glasbo kot del vsakdanjega življenja bodisi podeželskega bodisi mestnega prebivalstva. Glasba, ki je obstajala le v ustnem izročilu, je bila vezana na vsakdanje življenje isti jezik govorečih skupnosti; tako so se njene meje bolj ali manj prekrivale s sicer spreminjajočimi se narodnostnimi mejami.

Gregorijanski koral oz. liturgično enoglasje. Sem sodi tako gregorijanski koral, latinsko liturgično petje, ki ima svoje korenine v zgodnjem srednjem veku, kot tudi $\mathrm{v}$ tradiciji gregorijanskega korala $v$ visokem in poznem srednjem veku nastale množice novih oficijev in posamičnih enoglasnih spevov. Latinsko liturgično enoglasje, ki se je začelo zapisovati v 9. stol., je bilo v visokem in poznem srednjem veku pisna glasbena kultura, ki se je prenašala preko ustreznih liturgično-glasbenih rokopisov in obstajala kot petje po glasbenem zapisu. Ta glasba ni bila vezana na narodnost, pač pa na cerkev in njeno organizacijo. Liturgično enoglasje, ki je obstajalo na Slovenskem, je bilo tako le sestavni del širših tokov znotraj liturgičnega enoglasja v latinski kulturi pripadajoči srednjeveški Evropi. Če bi na Slovenskem obstoječe liturgično enoglasje hoteli razmejevati, bi se morali pri tem ozirati na cerkvene, ne na narodnostne meje. Tako bi bilo mogoče govoriti o oglejski liturgiji in oglejskem liturgičnem petju na oglejskemu patriarhatu pripadajočih področjih, o liturgičnem enoglasju v salzburški škofiji severno od Drave. Vendar je treba ob tem načelnem izhodišču omeniti, da so na dejansko podobo liturgičnega enoglasja poleg cerkvenih vplivale tudi politične meje: liturgični rokopisi s habsburških, oglejskemu patriarhatu pripadajočih ozemelj so drugačni od onih v sosednjih romanskih pokrajinah (npr. v Kopru). Nadalje je pri obravnavi liturgičnega enoglasja na Sovenskem potrebno ločevati sekularne (župnije, kapitlji, škofije) ustanove od samostanskih. Liturgično enoglasje v slovenskih cistercijanskih samostanih sodi v vsebinski sklop cistercijanske predelave liturgije in liturgičnega petja. Podobno je mogoče reči za kartuzijane, frančiškane in druge na Slovenskem obstoječe samostanske skupnosti. Pravi okvir obravnavanja

13 J. Mlinarič, nav. delo, str. 73-74.

${ }^{14}$ Pregled kleriških skupnosti podaja: France Martin Dolinar, Svetne in redovne kleriške skupnosti v srednjem veku na Slovenskem, Srednjeveška glasba na Slovenskem in njene evropske vzporednice, ur. Jurij Snoj, Ljubljana, Založba ZRC, 1998, str. 29-37. 
rokopisov ljubljanskega frančiškanskega samostana je tako frančiškanska liturgija (ne pa liturgija v oglejskem patriarhatu). Če obrnemo gledišče, lahko rečemo, da je na slovensko ozemlje v srednjem veku skladno z njegovo cerkveno zgodovino pljusknilo več različnih liturgičnih in koralnih izročil.

Glagoljaško petje. Na ozemeljsko ozkem pasu ob morju je verjetno obstajalo tudi glagoljaško liturgično petje. Z večjo gotovostjo ga je mogoče predpostaviti za glagoljaški frančiškanski samostan v Kopru. Glagoljaška liturgija je v poznem srednjem veku kot liturgija sledila liturgiji rimske kurije, katere besedila so bila prevajana v staro cerkveno slovanščino in zapisovana $\mathrm{v}$ glagolici. Osrednji repertoar melodij, po katerih naj bi se pela liturgična besedila, je bil zelo verjetno izpeljan iz gregorijanskega korala, le da so bile melodije prilagojene slovanskim besedilom.

Komponirano večglasje. Dopustiti moremo možnost, da je na Slovenskem sporadično, mestoma obstajalo srednjeveško umetno večglasje. Večglasje so lahko gojila le tista okolja, kjer so bili glasbeno pismeni in izobraženi glasbeniki.

Minnesang. Zdi se, da je na slovenskem ozemlju obstajal tudi srednjeveški nemški minnesang, katerega nosilec bi moglo biti nemško govoreče plemstvo. Čeprav je bil minnesang pisna kultura, so melodije, glasba, po kateri so se pele posamezne pesmi, obstajale prvenstveno v ustnem izročilu.

\section{Viri}

O vsem navedenem je mogoče govoriti na osnovi virov in tako se postavlja vprašanje: Kateri znani viri oz. zvrsti virov omogočajo spoznavanje posameznih na Slovenskem obstajajočih glasbenih zvrsti in razpravljanje o njih?

Glasba v ustnem izročilu. Da se glasba vsakdanjega življenja, tista, ki je bila vezana na slovenski jezik in druge občevalne jezike, ni zapisovala, pač pa obstajala le v ustnem izročilu, je skladno z načinom njenega obstoja. Strogo vzeto, te glasbe kot otipljivega predmeta raziskovanja ni. O njej pričajo najredkejše in slučajne omembe petja, zapisi nekaj petju namenjenih besedil ter ikonografski viri, se pravi likovne upodobitve glasbil ali plesa. Število virov za srednjeveško ustnoizročilno glasbo, pa tudi za nekatere druge glasbene zvrsti, se nekoliko poveča, če jim priključimo še pisce 16. stol., med katerimi so zlasti slovenski reformatorji. Nastop protestantizma ali reformacije je bil po več stoletjih prvo večje, širše družbene plasti zajemajoče gibanje. V slovenski kulturni zgodovini se je vse do pojava protestantskih pesmaric bolj ali manj nepretorgoma nadaljevalo izročilo srednjeveškega ustnoizročilnega petja. Ko govorijo o svojem času in okolju (bodisi v slovenskih ali nemških spisih), pričajo pisci 16. stol. o srednjeveškem izročilu. Prav zaradi tega jih je mogoče upoštevati tudi pri razpravljanju o podobi vsakdanjega življenja v poznem srednjem veku na Slovenskem. ${ }^{15}$

Doslej znane srednjeveške omembe ustnoizročilnega petja na Slovenskem lahko

${ }^{15}$ Domala vse, kar je bilo v 16. stol. napisano o glasbi na Slovenskem, je zbrano in komentirano v delu: Andrej Rijavec, Glasbeno delo na Slovenskem v obdobju protestantizma, Ljubljana, Slovenska matica, 1967. 
preštejemo na prste. A čeprav so skope in slučajne, dopuščajo rekonstruiranje glasbenega prizora, ki ga omenjajo, in razmišljanje o njegovem kontekstu. Ob skupnem pregledu tovrstnih omemb je treba opozoriti, da jih ločijo stoletja in da izhajajo iz različnih okolij srednjeveškega vsakdanjika; prav zato med njimi ni mogoče vzpostaviti prepričljive povezave. Najstarejša in najbolj znana je omemba slovenskega petja v nemško pisanem spisu, znanem kot Schwabenspiegel, ki se je ohranil v dveh prepisih iz 14. in 15. stol. in v katerem je opisano ustoličevanje koroških vojvod. Tu je izrecno navedeno, da so ljudje ob ustoličenju peli v slovenskem jeziku: »pojejo njihovo slovensko pesem, njihov kirielejson «. ${ }^{16}$ Več omemb glasbe najdemo v stoletje mlajšem Santoninovem potopisu s konca srednjega veka; petje in igranje, ki zelo verjetno sodi v sklop ustnega izročila, čeprav najbrž ne slovenskega, je Santonino slišal pri župniku v Tržiču, v Konjicah in na Ptuju. ${ }^{17}$ Tudi pisci 16. stol. večkrat omenjajo petje, instrumente, ples, in del teh omemb bi bilo mogoče razumeti v sklopu tradicije ustnoizročilne glasbe.

Pravi srednjeveški zapisi petju namenjenih besedil so se ohranili le v enem od stiških rokopisov. Kot je dobro znano, vsebuje rokopis NUK, Ms 141 med slovenskimi besedili tudi dve pesniški: Naš gospud in Češčena bodi, ${ }^{18}$ katerih zapisa sta bila postavljena v leti 1440 in $1428 .{ }^{19}$ Ti besedili sta prevoda oz. slovenski prepesnitvi nemške pesmi Christ ist erstanden ter marijanske latinske antifone Salve regina. Besedili, po katerih sta bila narejena prevoda, sta bili namenjeni petju in zato je mogoče domnevati, da sta se peli tudi prevedeni v slovenščino, in sicer najverjetneje po njunih siceršnjih melodijah. Ti melodiji sta bili z nemškim oz. latinskim besedilom večkrat zapisani, ${ }^{20}$ a s slovenskimi besedili sta obstajali skoraj gotovo le v ustnem izročilu.

Z glasbo v vsakdanjem življenju bi bilo mogoče povezati tudi likovne upodobitve glasbil, glasbenih in plesnih prizorov. Teh upodobitev je veliko, ${ }^{21}$ vendar je ob njih, kot ob

${ }^{16}$ Ivan Grafenauer, Najstarejši slovenski “kirielejsoni”, Glasnik muzejskega društva za Slovenijo 23 (1942), str. 63. - Slovensko petje, in sicer v Tolminu, je omenjeno tudi v življenjepisu oglejskega patriarha Filipa II. (Philippe d'Alençon, 1381-1387), ki ga je napisal Marcantonio Nicoletti (ok. 1536-1596) iz Čedada. Navedeno po omembi v delu: Dragotin Cvetko, Zgodovina glasbene umetnosti na Slovenskem 1, Ljubljana, DZS, 1958, str. 17; isti, Slovenska glasba v evropskem prostoru, Ljubljana, Slovenska matica, 1991, str. 12.

${ }^{17}$ V cerkvi sv. Marije v bližini Tržiča so peli ob nekem brenkalu, ki ga je imel župnik (Giuseppe Vale, Itinerario di Paolo Santonino in Carintia, Stiria e Carniola negli anni 1485-1487, Rim, Biblioteca apostolica Vaticana, 1943, str. 188 (slovenski prevod: Paolo Santonino, Popotni dnevniki, prev. Primož Simoniti, Celovec, Dunaj, Ljubljana, Mohorjeva založba, 1991.); v Konjicah sta večerjo spremljala dva piskača (G. Vale, nav. delo, str. 228); na Ptuju so piskači igrali za ples (nav. delo, str. 239). - Santoninove omembe so bile z glasbenozgodovinskega stališča že večkrat komentirane, zadnjič v razpravi: Primož Kuret, Popotni dnevniki Paola Santonina 1485-1487, Srednjeveška glasba na Slovenskem in njene evropske vzporednice, ur. Jurij Snoj, Ljubljana, Založba ZRC, str. 174-177.

${ }^{18}$ Faksimile: Stiški rokopis, ur. Mihael Glavan, Monumenta Slovenica 2, Ljubljana, Slovenska knjiga, 1992.

${ }^{19}$ Ivan Grafenauer, Stiški (ljubljanski) rokopis, Dom in svet 29 (1916), str. 239, 243.

${ }^{20}$ Antifona Salve regina je prisotna tudi v bistrskem kartuzijanskem gradualu iz 13. stol., NUK, Ms 22.

${ }^{21}$ Upodobitve glasbil obravnava: Primož Kuret, Glasbeni instrumenti na srednjeveških freskah na Slovenskem, Ljubljana, Slovenska matica, 1973. - Prizori s plesom so predstavljeni v delu: Metoda 
glasbenoikonografskih virih nasploh, potrebna previdnost. Naslikani prizori ali glasbila so pogosto le v posredni zvezi z realnostjo, saj je bilo srednjeveško slikarstvo bolj kot realnosti zavezano lastnemu ikonografskemu izročilu. Kar vidimo na slikah, niso nujno realni prizori iz srednjeveškega glasbenega življenja. A tudi v primerih, ko je za sliko mogoče predpostavljati vsakdanjo resničnost, nikakor ni nujno, da bi ta obstajala v slikarjevem okolju. Dejstvo, da je nekje naslikano glasbilo, še zdaleč ne pomeni, da je takšno glasbilo obstajalo tam, kjer je slika nastala, niti ne pomeni, da ga je slikar kdaj v resnici videl.

Osrednji del ustnoizročilnega sklopa zapolnjuje slovenska srednjeveška ljudska pesem. Slovensko ljudsko pesništvo ni bilo pisna kultura in se zato tudi ni zapisovalo. Kakšna naj bi bila slovenska ljudska pesem v srednjem veku, o tem si je mogoče ustvariti predstavo le na osnovi kasnejših zapisov. Slovensko ljudsko izročilo se je, kot je dobro znano, začelo intenzivno in načrtno zbirati v 19. stol. Zbiratelji so se zanimali sprva za besedila, kasneje tudi za melodije. V zbranem gradivu so se prepoznavale plasti in sestavine iz različnih obdobij in tako tudi tiste iz obdobja srednjega veka. Razpravljanje o zgodovini slovenske ljudske pesmi na osnovi novodobnih zapisov in iskanje srednjeveških sestavin v njej sodi danes v področje etnomuzikologije in ne zgodovine glasbe.

Liturgično enoglasje. Tri vrste virov pričajo o gregorijanskem koralu oz. o liturgičnem enoglasju na Slovenskem: koralni rokopisi, v katerih je glasba sama zapisana, omembe liturgičnega petja $\mathrm{v}$ različnih zgodovinskih dokumentih, zlasti ustanovnih listinah, ter glasbenoteoretično spisje. Kot je bilo omenjeno, je bilo liturgično enoglasje pisna glasbena kultura, ki je realno obstajala kot petje po glasbenem zapisu. Prav zaradi tega je dejstvo, da je gregorijanski koral ohranjen v obliki glasbenih zapisov, skladno z načinom njegovega obstoja. Z najredkejšimi izjemami je liturgično enoglasje edina od srednjeveških, na Slovenskem obstoječih glasbenih zvrsti, ki se je ohranila in jo je mogoče spoznavati in preučevati.

Gregorijanski koral je imel burno zgodovino. V visokem in poznem srednjem veku se je osnovni gregorijanski repertoar neprestano množil z novimi in novimi tvorbami, zlasti z novimi svetniškimi oficiji; obenem so se v skriptorijih za potrebe vse številnejših ustanov stalno izdelovali novi rokopisi, ki so poleg osnovnega repertoarja vključevali tudi novonastale tvorbe. Produkcija liturgično-glasbenih rokopisov je bila v poznem srednjem veku nepregledno velika in nepregledno obsežen je postajal tudi celotni repertoar spevov, kot je obstajal v latinski liturgiji pripadajočih evropskih deželah. Vendar je bil ta kontinuirani razvoj srednjeveškega liturgičnega enoglasja v 16. stol. prekinjen. Novonastale reformirane cerkve so srednjeveško latinsko liturgijo in z njo tudi liturgično enoglasje skoraj v celoti odklonile; a tudi v katoliških deželah sta bila, sledeč smernicam Tridentinskega koncila, liturgično enoglasje in srednjeveška liturgija očiščena vsega, kar ni bilo v skladu z novim, humanistično usmerjenim duhom časa. ${ }^{22}$ Vse to se odraža $\mathrm{v}$ načinu ohranitve srednjeveškega koralnega rokopisja. Že v srednjem veku so bili mnogi koralni rokopisi, ki se niso več rabili, bodisi odtujeni bodisi uničeni; zlasti pa se je iz

Kokole, Nekaj pričevanj o evropskem poznosrednjeveškem plesu na Slovenskem, Srednjeveška glasba na Slovenskem in njene evropske vzporednice, ur. Jurij Snoj, Ljubljana, Založba ZRC, str. 95-108.

${ }^{22}$ Kenneth Levy [in drugi], Plainchant, The New Grove Dictionary of Music and Musicians. Second edition 19, London, Macmillan, 2001, str. 849-852. 
omenjenih razlogov liturgično in koralno rokopisje odtujevalo in uničevalo v 16. in 17. stol. V tem času je bilo uničeno na tisoče liturgičnih kodeksov, njihovi pergamentni foliji pa porabljeni v druge namene, predvsem kot knjigoveško gradivo - kot zalepki, trakovi, ovitki na platnicah drugih, mlajših vezanih rokopisov in knjig. Domala vsaka evropska knjižnica ali arhiv, ki hrani gradivo izpred sredine 18. stol., ima tudi kot knjigoveško gradivo ohranjene ostanke srednjeveških rokopisov in število na ta način ohranjenih folijev gre v deset in sto tisoče. Koralni rokopisi, ki se niso več rabili, so lahko menjali lastnike, zlasti pa so lahko menjale lastnike druge, mlajše knjige, med katerimi so bile tudi take, ki so bile vezane v pergamentne folije iz uničenih srednjeveških kodeksov. To pomeni: mnogi rokopisi ali fragmenti rokopisov se danes hranijo drugje, kot so nastali in drugje, kot so bili uporabljani. Ko govorimo o rokopisih kot virih za liturgično enoglasje na Slovenskem, moramo torej upoštevati: Rokopisi, ki so bili v rabi na Slovenskem, se lahko hranijo tudi drugje, in obratno: dejstvo, da se rokopis hrani v kateri od slovenskih knjižnic, še ne pomeni, da je bil tu tudi dejansko v rabi, še zlasti pa ne pomeni, da je tu tudi nastal. V še večji meri velja vse to tudi za ohranjene folije iz uničenih knjig. V slovenskih hraniščih ohranjeni fragmenti srednjeveških glasbenih rokopisov niso nujno ostanki tu uporabljanih knjig, in obratno: možno je, da se posamični listi iz uničenih slovenskih rokopisov hranijo zunaj slovenskih meja.

V nadaljevanju naj bo kratko predstavljeno vse tisto koralno rokopisje, ki se ne glede na svoj izvor hrani v slovenskih knjižnicah in arhivih, za tem pa tisti s slovenskega prostora izvirajoči rokopisi, ki se hranijo drugje. Če jih gledamo kot knjižne enote (kodekse), je v slovenskih knjižnicah 23 srednjeveških koralnih rokopisov (gl. tabelo 1); eden od teh je močno nepopoln, saj obsega le 59 listov. Poleg tega je tu množica več sto folijev iz uničenih koralnih knjig, ohranjenih predvsem kot knjigoveško gradivo. K temu moramo dodati še nekaj neštevilnih posamičnih glasbenih vpisov v sicer neglasbene kodekse, bodisi da so ti ohranjeni v celoti ali pa le kot nekajlistni fragmenti. Takšen vpis je npr. v stiškem rokopisu NUK, Ms 8/III, ki je opisan v nadaljevanju.

Pravkar omenjeni, nepopolno ohranjeni kodeks je od vseh najstarejši. Po svoji vsebini je gradual, pisan $\mathrm{v}$ francoskih nevmah na črtovju oz. v cistercijanski notaciji. Kot izhaja iz njegovega sanktorala, je nastal na prehodu 12. v 13. stol. Rokopis je nedvomno cistercijanski, in čeprav ni direktnega kazalca o njegovem nastanku in uporabi, izhaja zelo verjetno iz cistercijanskega samostana v Stični. ${ }^{23} \mathrm{Na}$ osnovi njegovih kodikoloških in paleografskih značilnosti je bila postavljena domneva, da je bil kopiran v sami Stični okoli leta $1180 .{ }^{24}$ Po starosti mu sledi gradual v kvadratni notaciji, ki je nastal v 13. stol. in za katerega se - zopet brez trdnega dokaza - domneva, da izhaja iz kartuzije Bistra. ${ }^{25}$

${ }^{23}$ Jurij Snoj, The Gradual of Stična / Sittich, Dies est leticie. Essays on Chant in Honour of Janka Szendrei, ur. David Hiley in Gábor Kiss, Musicological Studies 90, Ottawa, The Institute of Mediaeval Music, str. 466-471, 475. Faksimila izbranih strani sta med drugim dostopna v delih: Nataša Golob, Stiški rokopisi iz 12. stoletja, Ljubljana, Narodna in univerzitetna knjižnica, 1994, str. 106; Jurij Snoj, Srednjeveški glasbeni kodeksi. Izbor reprezentativnih primerov iz slovenskih knjižnic, Ljubljana, ZRC SAZU, 1997, str. 49.

${ }^{24}$ Nataša Golob, Srednjeveški kodeksi iz Stične. XII. stoletje, Monumenta Slovenica 4, Ljubljana, Slovenska knjiga, 1994, str. 165-167.

${ }^{25}$ Milko Kos in France Stele, Srednjeveški kodeksi v Sloveniji, Ljubljana, Umetnostno-zgodovinsko 
Po svoji vsebini je nedvomno kartuzijanski. ${ }^{26} \mathrm{Iz} 14$. stol. je pontifikal, prepis pontifikalne knjige, kot jo je v 13. stol. izoblikoval Guillaume Durand. Ta rokopis, ki se za glasbo poslužuje kvadratne notacije, ni povezan z zgodovino slovenskega prostora. Večje število kodeksov, kar 7, se je ohranilo v koprski stolnici: gradual v dveh delih in antifonal v petih delih (prvotno jih je bilo 6, a za enega danes ni znano, kje je). Koprski kodeksi, pisani v kvadratni notaciji, ne predstavljajo popolnoma enovite celote. Prvi del graduala je iz 14. stol., antifonalni kodeksi pa skoraj gotovo iz 15. stol., vendar ne iz istega časa, saj so delo več različnih piscev. ${ }^{27}$ Tudi vsi nadaljnji, v slovenskih knjižnicah ohranjeni koralni rokopisi so iz 15. ali zgodnjega 16. stol. V novomeškem frančiškanskem samostanu sta dva graduala, pisana v kvadratni notaciji. Kot je razvidno iz njegovega eksplicita, je bil starejši od njiju izdelan leta 1418. Čeprav sta se ohranila v frančiškanskem samostanu in bila tu morda tudi v rabi, sta ta dva rokopisa po svoji vsebini kartuzijanska in možno je, da sta nastala v Žičah. Nadalje je iz 15. stol. psalter, pisan v kvadratni notaciji, ki izhaja sicer iz pleterske kartuzije, vendar je bil po najnovejših ugotovitvah kopiran in najbrž tudi uporabljan v Žičah. ${ }^{28} \mathrm{~V}$ kvadratni notaciji je tudi štiridelni antifonal, ki se hrani v Izoli in izhaja iz tamkajšnjega kapitlja. Čisto ob koncu 15. stol. je bil za kranjsko župnijsko cerkev sv. Kancijana kompiliran dvodelni antifonal, pisan v gotski notaciji. V eksplicitu njegovega prvega dela beremo, da ga je leta 1491 izdelal Ioannes von Werd de Augusta. ${ }^{29}$ Iz približno istega ali le nekoliko mlajšega časa so tudi dvodelni gradual ter enodelni antifonal oz. diurnal iz Frančiškanskega samostana v Ljubljani. Ti rokopisi, pisani v kvadratni notaciji, so po svoji vsebini nedvomno frančiškanski. ${ }^{30}$ Slednjič lahko z določenimi pomisleki glede časa nastanka štejemo k srednjeveškim kodeksom še papirnati pasijonal, pisan v gotski notaciji, enaki, kot jo vidimo v kranjskem antifonalu.

Posebno problematiko predstavljajo že opisani fragmenti - posamični listi ali manjši odrezki iz uničenih koralnih kodeksov, ki so se ohranili kot knjigoveško gradivo v vezavah drugih, mlajših knjig. Pred časom so bila z namenom, najti vse, tudi najmanjše ostanke srednjeveških glasbenih rokopisov, sistematično pregledana vsa ljubljanska hranišča. Ob tem je bilo najdeno in popisano okoli 550 pergamentnih folijev ali manjših odrezkov z glasbenim zapisom. Rekonstrukcija tega gradiva je pokazala, da pripada približno 175

društvo, 1931, str. 118.

${ }^{26}$ Jurij Snoj, Graduals from the Charterhouses Žiče (Seiz) and Bistra (Freudenthal), Papers read at the 13th meeting of the IMS Study group Cantus Planus, ur. Barbara Haggh, László Dobszay, Budapest, Institute for Musicology of the Hungarian Academy of Sciences, 2009, str. 579-580. Faksimile strani iz rokopisa je dostopen v delu: J. Snoj, Srednjeveški glasbeni kodeksi, str. 43.

${ }^{27}$ Jurij Snoj, Koralni kodeksi koprske stolnice, De musica disserenda 1/1-2 (2005), str. 115-127, 133-135. Tu so objavljeni tudi faksimili posamičnih strani.

${ }^{28}$ Nataša Golob, Srednjeveški rokopisi iz kartuzije Žiče (1160-1560), Ljubljana, Narodna galerija, 2006, str. 90. Faksimile ene od strani rokopisa je na str. 91. Druga stran rokopisa je faksimilirana v delu: J. Snoj, Srednjeveški glasbeni kodeksi, str. 46.

${ }^{29}$ Faksimilna izdaja: Antiphonarium ecclesiae parochialis urbis Kranj, ur. Jurij Snoj in Gabriella Gilányi, Musicalia Danubiana 23, Budapest, Magyar tudományos akadémia Zenetudományi intézet, 2007. O rokopisu gl. str. 8-10. Faksimile dveh strani je dostopen v delu: J. Snoj, Srednjeveški glasbeni kodeksi, str. 39-40.

${ }^{30}$ Jurij Snoj, The Franciscans in Carniola and their Chant (v tisku). Faksimile strani iz sanktoralnega dela graduala je dostopen v delu: J. Snoj, Srednjeveški glasbeni kodeksi, str. 55. 
Tabela 1: Koralni rokopisi v slovenskih hraniščih*

\begin{tabular}{|l|c|c|c|c|}
\hline Tip rokopisa & Čas nastanka & Notacija & Kraj uporabe & Hranišče \\
\hline gradual & zgodnje 13. stol. & cistercijanska & Stična & ARS, 1080 (Coll. I, 1) \\
\hline gradual & 13. stol. & kvadratna & Bistra & NUK, Ms 22 \\
\hline pontifikal & 14. stol. & kvadratna & & NUK, Ms 19 \\
\hline gradual: temporal & 14. stol. & kvadratna & Koper: stolnica & ŠAK \\
\hline gradual: sanktoral & 14. stol. & kvadratna & Koper: stolnica & ŠAK \\
\hline antifonal: temporal I & 15. stol. & kvadratna & Koper: stolnica & ŠAK \\
\hline antifonal: temporal II & 15. stol. & kvadratna & Koper: stolnica & ŠAK \\
\hline antifonal: temporal III & 15. stol. & kvadratna & Koper: stolnica & ŠAK \\
\hline antifonal: sanktoral & 15. stol. & kvadratna & Koper: stolnica & ŠAK \\
\hline antifonal: skupni del & 15. stol. & kvadratna & Koper: stolnica & ŠAK \\
\hline gradual & 1418 & kvadratna & Fr. sam. Nm. & Fr. sam. Nm. \\
\hline gradual & 15. stol. & kvadratna & Fr. sam. Nm. & Fr. sam. Nm. \\
\hline psalter & 15. stol. & kvadratna & Kartuzija Žiče & NUK, Ms 21 \\
\hline antifonal: temporal I & 15. stol. & kvadratna & Izola: kapitelj & ŽU Izola \\
\hline antifonal: temporal II & 15. stol. & kvadratna & Izola: kapitelj & ŽU Izola \\
\hline antifonal: sanktoral & 15. stol. & kvadratna & Izola: kapitelj & ŽU Izola \\
\hline antifonal: skupni del & 15. stol. & kvadratna & Izola: kapitelj & ŽU Izola \\
\hline antifonal I & 1491 & gotska & Kranj: župnija & NŠAL, Rkp 18 \\
\hline antifonal II & ok. 1491 & gotska & Kranj: župnija & NŠAL, Rkp 19 \\
\hline gradual I & $15 . / 16$. stol. & kvadratna & Fr. sam. Lj. & Fr. sam. Lj. \\
\hline gradual II & $15 . / 16$. stol. & kvadratna & Fr. sam. Lj. & Fr. sam. Lj. \\
\hline antifonal & $15 . / 16$. stol. & kvadratna & Fr. sam. Lj. & Fr. sam. Lj. \\
\hline pasijonal & $15 . / 16$. stol. & gotska & & NUK, Ms 248 \\
\hline ARS: Ariv Repastan
\end{tabular}

ARS: Arhiv Republike Slovenije; ŠAK: Škofijski arhiv Koper; Fr. sam. Nm: Frančiškanski samostan Novo mesto; ŽU: župnijski urad; Fr. sam. Lj.: Frančiškanski samostan Ljubljana; NŠAL: Nadškofijski arhiv Ljubljana

različnim, nekdaj popolnim, kasneje pa uničenim kodeksom. Mnogi od teh so v ljubljanskem gradivu prisotni zgolj v obsegu enega samega folija ali pa celo manjšega odrezka, ki pa vendarle priča o nekdanjem obstoju nekega kasneje sicer uničenega rokopisa. Velika večina rokopisov, katerih sledi so se na ta način ohranile v Ljubljani, ni bila v uporabi na Slovenskem oz. na Kranjskem, saj se upravičeno domneva, da so njihovi posamični listi zašli sem le slučajno, in sicer skupaj s knjigami, v vezavah katerih so se ohranili. Vendar je za nekatere od tako ohranjenih folijev mogoče predpostavljati, da so iz rokopisov, ki so bili vsaj v času svojega uničenja, morda pa tudi pred tem, v Ljubljani oz. na Slovenskem. Primeri, ko so se listi iz istega kodeksa ohranili na platnicah več različnih, vendar iz približno istega časa izvirajočih knjig, nakazujejo, da je bil kodeks v času uničenja tu in da so se posamezni pergamentni listi po potrebi sproti rezali iz njega. Vendar je prisojanje fragmentarno ohranjenih rokopisov posameznim ustanovam zaradi njihove vsebinske nepopolnosti v vsakem primeru hipotetično. ${ }^{31}$

${ }^{31}$ Jurij Snoj, Fragments of Medieval Music Codices in Ljubljana Archives and Libraries, Interpreting 
Nekateri na Slovenskem nastali ali tu uporabljani rokopisi se zdaj hranijo drugje. V Mestnem muzeju v Boznu je notirani misal, ki ga je po navedbi v eksplicitu leta 1296 kompiliral Ruotlibus de Laybaco, 'Ruotlib iz Ljubljane'. ${ }^{32}$ Ruotlib je bil poklicni skriptor, ki je konec 13. in na začetku 14. stol. deloval v Ljubljani. ${ }^{33}$ Njegov v nemških nediastematskih nevmah notirani misal je bil zelo verjetno izdelan tu, a za koga je rokopis nastal in kje je bil v rabi, ni znano.

Tabela 2: Koralni rokopisi iz kartuzije Žiče ${ }^{34}$

\begin{tabular}{|l|c|c|}
\hline Nahajališče & Tip rokopisa & Stoletje oz. leto nastanka \\
\hline A-Gu, Ms 273 & antifonal & 13. stol. \\
\hline CZ-Pu, VII F 11 & psalter & 13. stol. \\
\hline GB-PM, ee. 18 (A. 28) & matutinal & 13./14. stol. \\
\hline CZ-Pu, XIII E 2 & gradual & 14. stol. \\
\hline A-Vn, Cod. 1866 & gradual & 14. stol. \\
\hline A-Gu, Ms 376 & gradual & 15. stol. \\
\hline A-Gu, Ms 7 & antifonal & 15. stol. \\
\hline A-Gu, Ms 18 & antifonal & 15. stol. \\
\hline A-Gu, Ms 21 & antifonal & 15. stol. \\
\hline A-Gu, Ms 51 & antifonal & 15. stol. \\
\hline A-Gu, Ms 145 & antifonal & 15. stol. \\
\hline A-Gu, Ms 556 & psalter & 15. stol. \\
\hline A-Vn, Cod. 1789 & antifonal & 1466 \\
\hline NUK, Ms 21 & psalter & 15. stol. \\
\hline
\end{tabular}

Zelo bogato koralno zapuščino ima kartuzija Žiče, kjer je bila po pričevanju P. Santonina tudi sicer obsežna knjižnica. ${ }^{35}$ Doslej je znano 14 glasbenih rokopisov, ki izvirajo iz te pomembne ustanove. ${ }^{36}$ Vprašanje, kateri od teh so v Žičah nastali in kateri so bili tam le

and collecting fragments of medieval books, ur. Linda L. Brownrigg in Margaret M. Smith, Los Altos Hills, Anderson Lovelace, London, The Red Gull Press, 2000, str. 152, 154-155.

${ }^{32}$ Bolzano, Museo Civico, Ms 1304. Rokopis je prvi opisal: Marco Gozzi, Tre sconosciuti manoscritti liturgici con notazione del Museo Civico di Bolzano, Studi Trentini di Scienze Storiche 82, Sezione 1-4, Trento 2003, str. 731-746. Tu so tudi faksimili več strani rokopisa. O vsebini rokopisa gl. Jurij Snoj, Ruotlibus de Laybaco in njegov notirani misal, Stoletja glasbe na Slovenskem, ur. Primož Kuret, Ljubljana, Festival, 2006, str. 180-187.

${ }^{33}$ Dušan Kos, Pismo, pisava, pisar, Ljubljana, Založba ZRC, 1994, str. 205.

${ }^{34}$ A-Gu: Gradec, Univerzitetna knjižnica; A-Vn: Dunaj, Avstrijska narodna knjižnica; CZ-Pu: Praga, Národni knihovna; GB-PM: Parkminster, St Hugh's Charterhouse.

${ }^{35}$ G. Vale, nav. delo, str. 257.

${ }^{36} \mathrm{Z}$ izjemo dveh so ti rokopisi vključeni v katalog vseh doslej znanih žiških kodeksov: Nataša Golob, Srednjeveški rokopisi iz kartuzije Žiče (1160-1560), str. 121-129 (katalog). Faksimili žiških glasbenih rokopisov so na str. 20, 30, 37, 45, 48, 49, 51, 55, 56, 57, 71, 87, 89, 91, 103. Osnovni podatki o teh rokopisih so dostopni tudi na spletnih straneh projekta Avstrijske akademije znanosti Musikalische Quellen des Mittelalters in der Österreichischen Nationalbibliothek, ki ga vodi Robert Klugseder, in na spletno dostopnem katalogu rokopisov Univerzitetne knjižnice v Gradcu, ki ga oskrbuje Hans Zotter. 
v rabi, ni docela pojasnjeno. ${ }^{37}$ En koralni rokopis, antifonal v kvadratni notaciji, ki je bil kopiran sredi 15. stol., se je ohranil tudi iz kartuzije Jurklošter (Gairach).$^{38} \mathrm{Ob}$ koncu tega pregleda naj bo omenjeno, da se v knjižnicah zunaj slovenskih meja zelo verjetno skriva še kateri doslej nepoznani, na Slovenskem uporabljani glasbeni kodeks. ${ }^{39}$

Druga vrsta virov za srednjeveško enoglasje so zgodovinski viri. Sem sodijo zlasti različne ustanovne listine, v katerih je predpisano peto koralno bogoslužje. V skladu s srednjeveškim načinom življenja so nekateri imovitejši posamezniki del svojega premoženja namenjali cerkvam, ki naj bi za to opravljale v ustanovni listini določeno bogoslužje. To je pogosto vključevalo tudi petje. Doslej je s slovenskega ozemlja znano 39 glasbo omenjajočih listin te vrste, od katerih ni nobena izpred 15. stol., a gotovo jih je več. ${ }^{40} \mathrm{Na}$ podoben način je peto bogoslužje izrecno določeno v ustanovni listini ljubljanske škofije oz. kapitlja iz leta $1461^{41}$ in tako je moralo biti tudi v izgubljeni ustanovni listini novomeškega kapitlja iz leta 1493.42 Poleg teh pričajo o koralnem bogoslužju še drugi dokumenti. Nekatere omembe glasbe iz Santoninovega popotnega dnevnika se zelo verjetno nanašajo na liturgično enoglasje; ${ }^{43}$ petje zadevajo posamezne določbe v statutu in protokolih ljubljanskega kapitlja, ki se večkrat dotikajo vprašanj v zvezi z opravljanjem oficija: ${ }^{44}$ podobne

${ }^{37} \mathrm{O}$ žiških glasbenih rokopisih so pisali: Rudolf Flotzinger, Die notierten mittelalterlichen Handschriften aus der Kartause Seiz, Srednjeveška glasba na Slovenskem in njene evropske vzporednice, ur. Jurij Snoj, Ljubljana, Založba ZRC, 1998, str. 51-65; Katarina Šter, Two antiphonals from the Carthusian monastery in Žiče: Manuscripts 273 and 7 from the Graz University Library, De musica disserenda 4/2 (2008), str. 7-20; Katarina Šter, Paleografske značilnosti rokopisa MS 273 iz Univerzitetne knjižnice v Gradcu, De musica disserenda 5/1 (2009), str. 107-135.

38 A-Gu, Ms 375. Gl. spletno dostopen katalog Univerzitetne knjižnice v Gradcu.

${ }^{39}$ Po Folnesicsu je bilo v koprskem frančiškanskem samostanu, konventu sv. Ane, 12 glasbenih rokopisov. Hans Folnesics, Die illuminierten Handschriften im österreichischen Küstenlande, in Istrien und der Stadt Triest, Beschreibendes Verzeichnis der illuminierten Handschriften in Österreich VII, ur. Franz Wickhoff in Max Dvořák, Leipzig 1917, str. 30-40, št. 26-37. Kje so ti rokopisi danes, ni znano.

${ }^{40}$ Zadnji obravnavi tovrstnih virov sta: Janez Höfler, Glasba v poznosrednjeveških beneficijih na Slovenskem, Srednjeveška glasba na Slovenskem in njene evropske vzporednice, ur. Jurij Snoj, Ljubljana, Založba ZRC, 1998, str. 85-94; Jurij Snoj, Zgodovinski viri o glasbenem življenju na Slovenskem do konca srednjega veka, 300 let. Academia Philharmonicorum Labacensium, ur. Ivan Klemenčič, Ljubljana, Založba ZRC, 2004, str. 114-116.

${ }^{41}$ Listina je objavljena v delu: Lilijana Žnidaršič Golec, Duhovniki kranjskega dela ljubljanske škofije do tridentinskega koncila, Acta Ecclesiastica Sloveniae 22, Ljubljana, Teološka fakulteta Univerze v Ljubljani, 2000, str. 307-313, zlasti str. 309.

${ }^{42}$ Slovenski povzetek nemškega regesta izgubljene listine pravi, da bodo kanoniki "opravljali skupno molitveno bogoslužje, kakor je navada v kolegiatnih cerkvah, in vsak dan peli jutranjo mašo". Gl. France Baraga, Kapiteljski arhiv Novo mesto. Regesti listin in popis gradiva, Acta Ecclesiastica Sloveniae 17, Ljubljana, Inštitut za zgodovino cerkve pri Teološki fakulteti Univerze v Ljubljani, 1995, št. 144, str. 97-98.

43 Škofjeloške klarise pojejo pri maši (G. Vale, nav. delo, str. 181). Velesovske dominikanke na više postavljenem koru pojejo pri maši s sladkimi glasovi in umetniško dovršeno (»per artem «, G. Vale, nav. delo, str. 187); dostavek, da je bilo to petje umetniško, nakazuje možnost, da je bilo večglasno.

${ }^{44}$ L. Žnidaršič Golec, nav. delo, str. 82-88. 
drobce o liturgičnem petju bi bilo mogoče najti tudi ob ustreznem študiju dokumentov drugih cerkvenih ustanov, predvsem samostanskih; slednjič se liturgično enoglasje večkrat omenja v spisih piscev 16. stol., zlasti reformatorskih, in čeprav izvirajo iz mlajšega časa, se te omembe nanašajo na staro, po izvoru še srednjeveško izročilo.

Tretja vrsta virov za liturgično enoglasje so srednjeveški glasbenoteoretični spisi. Znani so trije: med stiškimi kodeksi, ki so bili kopirani v 12. stol., je kopija spisa Etymologiarum sive originum libri Izidorja iz Sevilje, ki vključuje med mnogimi poglavji, $»$ knjigami«, tudi knjigo o glasbi; ${ }^{45}$ v enem od rokopisov iz kartuzije Bistra, kompiliranem v 14. stol., je daljša jezikoslovna razprava, ob koncu katere je prikaz recitacijskih glasbenih obrazcev; ${ }^{46}$ slednjič je v fragmentarno ohranjenem gradivu folij, ki vsebuje odlomka iz dveh razprav Gvida Areškega: Micrologus in Prologus in Antiphonarium. Rokopis, ki mu je ohranjeni folij pripadal, izvira iz 12. stol.; njegov izvor ni pojasnjen. ${ }^{47}$

Glagoljaško petje. O glagoljaški liturgiji in glagoljaškem petju bi lahko posredno pričali fragmentarno ohranjeni ostanki glagoljaških liturgičnih knjig, ki so se - podobno kot fragmenti koralnih kodeksov - ohranili kot knjigoveško gradivo. V slovenskih knjižnicah je razmeroma veliko število posamičnih pergamentnih listov iz uničenih glagoljaških misalov in brevirjev. Ker nimajo glasbenega zapisa, pričajo le o obstoju glagoljaške liturgije, ne pa tudi o glagoljaškem petju. Kje natančno so bili rokopisi, ki so jim tako ohranjeni listi nekdaj pripadali, v rabi, ni znano: morda je kateri iz glagoljaškega samostana v Kopru, morda je bil kateri v lasti kakega v obalnem pasu delujočega glagoljaškega duhovnika, možno pa je tudi, da izvirajo s hrvaškega primorja, kjer je bilo glagoljaštvo običajno. ${ }^{48}$ Od tovrstnih virov se loči dvolistni, v NUK najdeni fragment, ki izhaja iz poznega 15. ali 16. stol. in na katerem je nekaj v glagolici zapisanih spevov z glasbenim zapisom v gotski notaciji. Medtem ko enega od zapisanih spevov ni bilo mogoče identificirati, imajo ostali štirje besedila in glasbo iz sočasnega latinskega repertoarja. Ta fragment skoraj gotovo ni povezan s slovenskim prostorom in je v Ljubljani zgolj slučajno. ${ }^{49}$ Poleg teh bi o glagoljaškem petju lahko pričali tudi viri v zvezi z edino izrecno glagoljaško ustanovo na Slovenskem, glagoljaškim frančiškanskim samostanom v Kopru..$^{50}$

Komponirano večglasje. Obstoj umetnega večglasja na Slovenskem nakazuje nekaj omemb iz poznega 15. in 16. stol. P. Santonino, avtor že omenjenega popotnega dnevnika, je bil sicer predvsem humanistično usmerjen literat, ki glasbe ni opisoval s poznavalsko preciznostjo. Kljub temu je nekatere njegove omembe mogoče razumeti tako, kot da se

${ }^{45}$ NUK, Ms 16. Faksimile strani je dostopen v delu: J. Snoj, Srednjeveški glasbeni kodeksi, str. 61.

${ }^{46}$ NUK, Ms 46, fol. 187v-190r. Faksimile strani je dostopen v delu: J. Snoj, Srednjeveški glasbeni kodeksi, str. 68.

${ }^{47}$ NUK, R (brez signature). Fragment je obravnavan v delu: Jurij Snoj, Ljubljanski prepis traktatov Gvidona Aretinskega, Muzikološki zbornik 28 (1992), str. 63-71. Faksimile dveh strani je dostopen v delu: J. Snoj, Srednjeveški glasbeni kodeksi, str. 64-65.

${ }^{48}$ Janez Zor, Glagolska pričevanja na Slovenskem, Bogoslovni vestnik 45/2 (1985), str. 183-191.

49 Jurij Snoj, The Glagolitic chant fragment from the National and University Library in Ljubljana (v tisku).

${ }^{50}$ Vjekoslav Štefanić, Glagoljaši u Kopru: G. 1467-1806, Zagreb, Jugoslavenska akademija znanosti i umjetnosti, 1956. (Objavljeno tudi v publikaciji Starine 46 (1956), str. 203-329.) 
nanašajo na umetno večglasje; slišal naj bi ga v kranjski župnijski cerkvi ter v Konjicah. ${ }^{51}$ Tudi nekaj deset let mlajši pisci 16. stol. večkrat omenjajo polifono glasbo ${ }^{52}$ in med njihovimi omembami sta znani zlasti dve: P. Trubar se spominja petglasnega petja v ljubljanski špitalski cerkvi, ${ }^{53}$ A. Bohorič pa leta 1582 ponuja svojo knjižnico v odkup deželnim stanovom; v njej naj bi bilo po njegovih besedah tudi ok. 2000 večglasnih kompozicij, tiskanih in rokopisnih. ${ }^{54}$

Druga skupina virov za komponirano večglasje na Slovenskem so ohranjeni zapisi posamičnih večglasnih kompozicij. Znani so trije: 1. Fragment v italijanski notaciji, ki sestoji iz nekaj drobnih odrezkov. Ohranjeni zapis je nepopoln in zelo težko čitljiv, zaradi česar zapisane glasbe, ki bi mogla pripadati italijanskemu večglasju 14. ali 15. stol., doslej ni bilo mogoče prepoznati. ${ }^{55}$ 2. Zapis triglasne nemenzurirane formule za petje jutranjičnih lekcij. Rokopis, na začetku katerega je formula zapisana, je iz 15. stol. in ohranil se je v knjižnici kranjskega župnišča. ${ }^{56} 3$. Dva papirnata lista, ostanek zvežčiča s kompozicijami 15. stol. Ohranjena glasba pripada franko-flamski polifoniji. ${ }^{57} \mathrm{Za}$ drugega in tretjega od navedenih virov obstajajo sicer nejasni kazalci, da sta bila v rabi na Slovenskem.

Minnesang. Edino, kar priča o obstoju minnesanga na Slovenskem, so ohranjena besedila treh pesnikov, ki so živeli na južnem Štajerskem. Najstarejši vir, v katerem so zapisana, je velika Manessejeva zbirka, ki je nastala na začetku 14. stol. in v kateri je zbrana vsa lirika v srednji visoki nemščini, ki jo je njen kompilator mogel najti. Pesmi zbirke so urejene po avtorjih in med njimi so tudi trije iz treh južnoštajerskih plemiških rodbin: Žovneški, Gornjegrajski ter Ostrovrški (v rokopisu so navedeni le s temi imeni: »von Suonegge«, »von Obernburg« in »von Scharpfenberg«). Čeprav je bil minnesang namenjen petju, Manessejeva zbirka ne vključuje melodij. ${ }^{58} \mathrm{O}$ glasbeni podobi nemškega minnesanga se tudi sicer ne ve veliko, saj se je ohranilo znatno manj melodij kot besedil in še te so šele iz 14. in 15. stol. Domneva se, da so se pesmi nemških pesnikov pele po

${ }^{51}$ V kranjski župnijski cerkvi so se pri maši glasile orgle ter pevci (G. Vale, nav. delo, str. 183, 184). Še bolj izrazito nakazuje večglasje opis iz Konjic (»figuratis notis cecinerunt«, G. Vale, nav. delo, str. 252, 254).

${ }^{52}$ Kot je bilo že omenjeno, so domala vsa glasbo na Slovenskem zadevajoča mesta v pisnih virih 16. stol. zbrana in obravnavana v delu: A. Rijavec, Glasbeno delo na Slovenskem v obdobju protestantizma.

${ }_{53}$ Primož Trubar, Eni psalmi, Tübingen 1567 (nemško pisano posvetilo Juriju Khislu). O tem razpravlja: A. Rijavec, nav. delo, str. 99-101.

${ }^{54}$ A. Rijavec, nav. delo, str. 139-143. Faksimile Bohoričevega pisma je na str. 140-141.

${ }^{55}$ NŠAL, Pergamentni ovitki z rokopisi, brez sign. O vsebini je pisal Janez Höfler, Menzuralni fragment iz Nadškofijskega arhiva v Ljubljani, Muzikološki zbornik 2 (1966), str. 12-17 (tu tudi faksimile); isti, Tokovi glasbene kulture na Slovenskem, Ljubljana, Mladinska knjiga, 1970, str. 20.

${ }^{56}$ Janez Höfler, Primer primitivnega srednjeveškega večglasja iz Kranja, Muzikološki zbornik 5 (1969), str. 5-9; J. Snoj, Srednjeveški glasbeni kodekci, str. 70-72 (tu tudi faksimile).

${ }^{57}$ Jurij Snoj, Dva lista z Binchoisovo in brezimno glasbo 15. stoletja v ljubljanski Narodni in univerzitetni knjižnici, Muzikološki zbornik 24 (1988), str. 5-20 (tu tudi faksimile).

${ }^{58}$ Anton Janko, Nikolaus Henkel, Nemški viteški liriki s slovenskih tal, Ljubljana, Znanstveni inštitut Filozofske fakultete, 1997, str. 12-13, 24-25. V navedenem delu so objavljene tudi same pesmi. 
različnih melodijah, ki so jih pesniki oz. pevci znali na pamet in ki so ustrezale posamičnim pesniškim oblikam. ${ }^{59}$ Verjetno so se tako pele tudi pesmi južnoštajerskih pesnikov.

\section{Zgodovina liturgičnega enoglasja na Slovenskem}

Nedvomno je imela vsaka od glasbenih zvrsti, ki so obstajale na Slovenskem, svojo časovno razsežnost, vendar dopušča zgodovinski pregled le liturgično enoglasje. Strogo vzeto je predpogoj zgodovine katere koli glasbene zvrsti to, da ni obstajala le v ustnem izročilu, pač pa v obliki pisne kulture. Podobno kot liturgično enoglasje je bilo pisna kultura tudi srednjeveško komponirano večglasje in ohranjeni drobci srednjeveškega večglasja na Slovenskem zaslužijo kar največjo študijsko pozornost. Vendar med njimi ni mogoče vzpostaviti prave zgodovinske povezave: italijansko večglasje 14. ali 15. stol. je zgodovinsko le posredno povezano s franko-flamsko polifonijo 15. stol., od obeh pa se močno oddaljuje nemenzurirano, "primitivno« večglasje. Nasprotno temu so ohranjeni, s slovenskega ozemlja izvirajoči koralni rokopisi - kljub temu, da pripadajo različnim tokovom, po svoji vsebini toliko medsebojno povezani, da skupaj z drugimi zgodovinskimi pričevanji o liturgičnem enoglasju vendarle omogočajo zgodovinsko interpretiranje, se pravi predstavitev v obliki zgodovine.

O obstoju gregorijanskega korala na Slovenskem pričajo ohranjeni rokopisi, poleg njih pa tudi omembe $\mathrm{v}$ zgodovinskih virih. Zgodovinski pregled mora upoštevati oboje. A kot je bilo prikazano, je bil marsikateri na Slovenskem uporabljani koralni rokopis bodisi uničen ali odtujen in najstarejši glasbeni kodeks, ki ga je z večjo mero gotovosti mogoče povezati s slovenskim ozemljem, je šele s prehoda 12. v 13. stol. Prav zaradi fragmentarnosti in izgube primarnih glasbenozgodovinskih virov, glasbenih rokopisov samih, je zgodovinski pregled večkrat prisiljen v zgodovinopisno deduciranje iz splošnega na posamično; na sklepanje, da je nekaj obstajalo zato, ker je bilo v splošnem tako tudi drugje.

Prav v smislu takšnega sklepanja je mogoče razmišljati o morebitni prisotnosti liturgičnega enoglasja v sklopu misijonske dejavnosti med predniki kasnejših Slovencev. Kot je znano, so bili ti skladno s cerkveno razmejitvijo pokristjanjeni po eni strani s severa, zlasti v sklopu salzburškega misijona, po drugi pa v sklopu oglejskega misijona. Salzburški misijon ima svoje začetke v 8. stol., ko je bila pokristjanjena družina karantanskega vojvode in ko je salzburški škof Virgil, eden od mnogih na kontinentu delujočih Ircev, poslal v Karantanijo, h Gospe Sveti, pokrajinskega škofa Modesta. ${ }^{60} \mathrm{O}$ pokristjanjevanju Slovanov južno od Drave, se pravi s strani oglejske cerkve, je manj znanega. Gotovo je bil v zgodnejšem času ena od ključnih osebnosti pri tem delu patriarh Pavlin II., ki je bil dejaven tudi pri dokončni določitve meje med salzburško in oglejsko cerkveno pokrajino. Znano je, da je Pavlin odkrito zagovarjal stališče, da pokristjanjevanje ni politično, ampak versko delovanje. ${ }^{61}$ Čas pokristjanjevanja Slovanov je bil čas, ko je latinska liturgija v

${ }^{59}$ Horst Brunner, Minnesang, Die Musik in Geschichte und Gegenwart 6, Kassel [...], Bärenreiter, 1997, stolpca 306-307.

${ }^{60}$ P. Štih in V. Simoniti, Na stičišču svetov, str. 35-38.

${ }^{61}$ Nav. delo, str. 52-53. O načinu pokristjanjevanja Slovanov govori med drugim spis Ordo de 
sklopu Frankovske države komaj dobivala ustaljeno obliko. Glasba se v tem času še ni zapisovala ali pa se je v nekaterih frankovskih središčih komaj začela zapisovati. Iz tega časa ni niti oglejskih niti salzburških liturgičnih rokopisov in niti o oglejskem niti o salzburškem liturgičnem petju ni za ta čas znano nič določnega. ${ }^{62}$ Razpravljanje o petju v sklopu zgodnje misijonske dejavnosti se mora zato ustaviti pri splošni domnevi z ohlapno vsebino: možno je, da je latinska liturgija med pokristjanjenimi Slovani vključevala tudi neko nedoločljivo petje, ki se ni zapisovalo, pač pa obstajalo le v ustnem izročilu.

Do podobne domneve more privesti tudi razmišljanje o misiji »slovanskih apostolov« Cirila in Metoda, ki sta se potem, ko sta odšla z Moravskega, ustavila pri slovanskem knezu Koclju, kjer naj bi bila v letih 869-870. ${ }^{63}$ Ciril, s pravim imenom Konstantin, in Metod sta bila Grka, ki sta vzpostavila slovansko bogoslužje. To bogoslužje je imelo za zgled sočasno grško, bizantinsko liturgijo in bizantinsko liturgično petje v grščini. A podobno kot na evropskem zahodu se je grško liturgično petje v 9. stol. komaj začelo zapisovati, saj so iz tega časa znani le danes nerazberljivi zapisi v ekfonetski notaciji. ${ }^{64}$ Toliko teže je reči kaj določnega o možni glasbeni podobi petja slovanskih liturgičnih besedil.

Govoreč o liturgičnem petju v 9. stol. naj bo vendarle omenjeno, da eden od spisov, ki poročajo o pokristjanjenju Slovanov, izrecno imenuje petje in nakazuje, da je v tistem daljnem času bogoslužje vendarle vključevalo tudi glasbo. Ta spis je Conversio Bagoariorum et Carantanorum, ki je pisan s stališča interesov salzburške škofije in prikazuje zato Metodovo delovanje - omenja le njega, v slabi luči. Tu izvemo, kako se je Pribina (Priwina) dve desetletji pred prihodom solunskih bratov naselil v močvirjih reke Zale (v »Blatenskem kostelu«, nekje ob izlivu Zale v Balaton), kjer je salzburški škof Liuprammus dne 24. 1. 850 posvetil novo cerkev sv. Marije. Ob tej priložnosti je bil navzoč tudi Pribinov sin Kocelj (Chezil). Škof je dovolil, da v tej cerkvi deluje duhovnik Dominik (Dominicus) in zanj vir izrecno pravi, da mu je dal dovoljenje »peti mašo« $\mathrm{v}$ njegovi, tj. salzburški škofiji, ki je takrat vključevala tudi Spodnjo Panonijo. ${ }^{65}$

Do začetka 12. stol. je bila na slovenskem ozemlju vzpostavljena mreža najstarejših župnij, ${ }^{66} \mathrm{ki}$ so bile v nadaljnjem času povezane v pokrajinsko razmejene arhidiakonate in

catechizandis rudibus iz 9. stol. Faksimile prve strani vsebuje Enciklopedija Slovenije 9, Ljubljana, Mladinska knjiga, 1995, str. 62. - Pavlin je bil tudi pesnik in v neki svoji pesmi omenja več slovenskih rek. Gl. Primož Simoniti, Florarium Mediaevale / Srednjeveški cvetnik, Ljubljana, Slovenska matica, 2000, str. 72-83.

${ }^{62}$ Glasbeni rokopisi z današnjega avstrijskega prostora so šele iz 11. in 12. stol.: Rudolf Flotzinger, Gernot Gruber, Musikgeschichte Österreichs 1. Von den Anfängen zum Barock, Dunaj, Köln, Weimar, Böhlau Verlag, 1995, str. 58. Tudi oglejski glasbeni rokopisi izvirajo šele iz časa od 12. stol. dalje: Raffaella Camilot-Oswald, Die liturgischen Musikhandschriften aus dem mittelalterlichen Patriarchat Aquileia, Monumenta monodica medii aevi, Subsidia 2, Kassel [...], Bärenreiter, 1997, str. XXIX-XXXI.

${ }^{63}$ P. Štih in V. Simoniti, Na stičišču svetov, str. 69.

${ }^{64}$ Kenneth Levy in Christian Troelsgård, Byzantine chant, The New Grove Dictionary of Music and Musicians. Second edition 4, London, Macmillan, 2001, str. 734.

65 »... licentiam ... missam canendi ...« Conversio Bagoariorum et Carantanorum, Sveta brata Ciril in Metod v zgodovinskih virih, Acta Ecclesiastica Sloveniae 7, Ljubljana, Teološka fakulteta v Ljubljani, 1985, str. 38.

${ }^{66}$ J. Mlinarič, Cerkev na Slovenskiem v srednjem veku, str. 70-71. 
prek arhidiakonov podrejene bodisi salzburški nadškofiji bodisi oglejskemu patriarhatu. ${ }^{67}$ Če spregledamo v političnem smislu beneško usmerjeno obalo, kjer je obstajala škofija že konec 6. stol., so vse do 15. stol. kot mesta svetnega (nesamostanskega) bogoslužja obstajale na Slovenskem le župnije. Šele v 15. stol. so se župnijam pridružile nekatere nove svetne (nesamostanske) liturgične skupnosti: škofija s kapitljem v Ljubljani ${ }^{68}$ ter kapitelj v Novem mestu. ${ }^{69}$

Kar zadeva sam liturgični red, ritus, naj bi vse nesamostanske cerkve na ozemlju oglejskega patriarhata sledile oglejskemu obredu, one severno od Drave pa salzburškemu. Vendar se ob študiju liturgičnih rokopisov pogosto vzbuja vtis, da je bila v srednjem veku, v obdobjih pred Tridentinskim koncilom, liturgična praksa razmeroma ohlapna: v dani cerkveni pokrajini, ki je imela svoj liturgični red, se niso nujno uporabljale le takšne liturgične knjige, ki bi strogo sledile veljavnemu liturgičnemu redu, pač pa tudi druge. V oglejskem delu bi se tako mogel uporabljati tudi rokopis s salzburškim ali kakim drugim liturgičnim redom, ali pa rokopis, ki bi bil kompilacija na osnovi več liturgičnih izročil oz. obredij.

Medtem ko si je za kapitlje in škofije laže predstavljati peto bogoslužje, se postavlja vprašanje, kako je v srednjem veku izgledalo bogoslužje v podeželskih ali mestnih župnijskih cerkvah, predvsem tistih, kjer je bilo malo duhovnikov ali pa en sam. To vprašanje nima razločnega odgovora, saj se liturgična in glasbena zgodovina raje posvečata drugim, pomembnejšim in preko virov - rokopisov - bolj oprijemljivim temam. Z izjemo kranjskega antifonala, ki si ga je konec 15. stol. omislila župnijska cerkve v Kranju, med ohranjenimi rokopisi ali njihovimi fragmenti ni nobenega, ki bi ga bilo mogoče zanesljivo prisoditi kateri od župnij. Župnijske cerkve najbrž niso imele koralnih rokopisov, saj jih tudi niso potrebovale: en sam duhovnik najbrž ni prepeval ne mašnega proprija niti ni opravljal petega oficija, za kar vse je bila potrebna večja skupina pevcev. Vendar je tudi za župnijske cerkve mogoče predvideti neke vrste latinsko liturgično petje. Da je obstajalo, je razvidno iz listin, tistih, ki izrecno omenjajo petje in se nanašajo na svetne, nesamostanske cerkve. Kot je bilo prikazano, so tovrstne listine šele iz 15. stol., vendar si je mogoče predstavljati, da je tisto, kar omenjajo za 15. stol., do določene mere obstajalo tudi že poprej.

Srednjeveške župnijske cerkve, kot so obstajale do izteka srednjega veka, so običajno imele le misal in brevir s psalterjem, kjer sta bili zapisani mašna in oficijska liturgija. Načeloma naj bi bili ti rokopisi v skladu z liturgičnim redom cerkvene pokrajine, oglejskega patriarhata ali salzburške škofije, vendar je bila realna praksa, kot je bilo že omenjeno, v tem pogledu ohlapna. Oficij se je najverjetneje opravljal privatno - duhovnik ga je bral sam, javna maša pa tako, da so bila petju namenjena besedila mašnega proprija le brana ali recitirana in najbrž ne peta. Peti bi mogli biti nekateri drugi deli maše. Misliti si je mogoče, da je celebrant pomnil nekaj preprostih koralnih glasbenih obrazcev, po katerih je lahko pel nekatera branju ali recitiranju namenjena proprijska besedila: mašno berilo, evangelij in mašne molitve. Temu bi bilo mogoče dodati še nekatere mašne speve, morda

\footnotetext{
${ }^{67}$ Nav. delo, str. $66-68$.

${ }^{68}$ Nav. delo, str. 73-74.

${ }^{69}$ Nav. delo, str. 84.
} 
tiste, ki so v sicer nenotiranih misalih včasih vendarle opremljeni z glasbenim zapisom. ${ }^{70}$ Med temi so mašne prefacije za različna obdobja oz. praznike liturgičnega leta in zaključni vzklik Ite missa est. Morda je poleg omenjenega srednjeveški duhovnik pomnil še nekatere zelo znane posamične gregorijanske speve, npr. velikonočni Exsultet iam angelica turba caelorum, ali pa marijansko antifono Salve regina. Ta je bila sicer del oficijske liturgije, vendar se je prepevala tudi zunaj svojega siceršnjega liturgičnega mesta, kar je med drugim razvidno iz dejstva, da je bila v 15. stol. prevedena v slovenščino. Čeprav so bili omenjeni glasbeni obrazci ter omenjeni spevi del gregorijanskega repertoarja, se pravi pisne glasbene kulture, je petje v župnijskih cerkvah zelo verjetno potekalo brez glasbenega zapisa; celebrant je pel po spominu, in sicer tisto, kar se je naučil v času svojega študija.

Kot je bilo prikazano, je latinsko liturgično petje v srednjeveških župnijskih cerkvah potekalo domnevno brez glasbenih zapisov. Če spregledamo samostane, se 13. stol. tako kaže kot v glasbenem pogledu nepismeni čas. In vendar je konec 13. in na začetku 14. stol. v Ljubljani deloval pisec, ki je leta 1296 kompiliral notirani misal: že omenjeni Ruotlibus. Ker je listinsko izpričano, da je Ruotlibus deloval v Ljubljani, je zelo verjetno, da je njegov v nemških adiastematskih nevmah pisani rokopis nastal tu. Ali je Ruotlibus kompiliral le besedila ali pa tudi glasbo, po katerih predlogah je rokopis izdelal, po čigavem naročilu in za koga, na vsa ta vprašanja bi lahko odgovorila posebna razprava. Kljub tem nejasnostim je z ozirom na to, da iz 13. in - z izjemo Kopra - tudi iz 14. stol. ni glasbenih rokopisov, ki bi izvirali iz svetnih, nesamostanskih cerkva, nastanek Ruotlibovega rokopisa presenetljiv.

Medtem ko je za starejši čas - za čas do 15. stol. - v zvezi z liturgijo svetnih cerkva komaj mogoče reči kaj izrecnega, je nekaj več znano o liturgičnem enoglasju slovenskih samostanov. Če odštejemo obalni pas, je najstarejši med slovenskimi samostani cistercijanski v Stični. O glasbi v zgodnjem obdobju tega samostana pričajo trije stiški rokopisi. Prvi je že omenjeni gradual, ki izvira s konca 12. ali začetka 13. stol. in po katerem je v samostanu potekalo mašno bogoslužje. Da je bil ta rokopis v rabi daljši čas, verjetno več stoletij, ne pričajo le obrabljeni robovi njegovih folijev, ampak tudi kasnejši vpisi, med katerimi so tudi razmeroma številni glasbeni. ${ }^{71}$ Obstoj nekaj glasbenoteoretičnega znanja nakazuje stiški prepis Izidorjevih Etimologij, ki vsebujejo tudi knjigo o glasbi. Vendar je treba ob tem omeniti, da je bila Izidorjeva teorija tudi v 12. stol. že davna preteklost; znanje, ki ga podaja, nikakor ne vključuje tistega, kar je bilo potrebno za razumevanje v stiškem gradualu zapisane glasbe. Tretji stiški glasbeni spomenik je pesem iz štirih petju namenjenih latinskih heksametrov, zapisana na začetku sicer neglasbenega kodeksa NUK, Ms 8/III iz 12. stol. Melodija, po katerih naj bi se peli, je ozko povezana z besedilom oz. obratno: besedilo je sestavljeno tako, da se vsaka beseda začne s črko, ki označuje ton, po kateri naj bi se peli vsi njeni zlogi. Poleg tega je ta melodija podana še s srednjeveškimi solmizacijskimi zlogi, zapisanimi nad posameznimi besedami pesmi. Pesem daje vtis, da je bila učno sredstvo za zapominjanje imen tonov in za osnovno spoznavanje tonskega

${ }^{70}$ Oglejski, leta 1494 v Augsburgu tiskani misal (izvod v NUK, 13 349), ima notirano tole: intonacije za Gloria in excelsis, intonacije za Credo, prefacije in vrsto melodij za zaključni Ite missa est oz. Benedicamus domino.

${ }^{71}$ J. Snoj, The Gradual of Stična / Sittich, str. 477-479, reprodukcije na str. 481-483. 
sistema. ${ }^{72}$ Taka nakazuje možnost glasbenega pouka. Stiški cistercijani so morali opravljati tudi oficij, a o ustreznem antifonalu ni nobenega sledu.

Drugi samostan z bogato glasbeno zapuščino je kartuzija Žiče, iz katere je znano 14 glasbenih rokopisov (gl. tabelo 2). Najstarejši med njimi je antifonal, ki je nastal najbrž konec 13. stol. Možno je, da je bil ta rokopis kopiran oz. kompiliran v Franciji, od koder je bil prenesen v Žiče. ${ }^{73}$ Oficijsko bogoslužje je v Žičah zelo verjetno potekalo po tem rokopisu, ki je bil domnevno tudi predloga, po kateri so bili kopirani ostali žiški antifonali. Čeprav so ti rokopisi nastali v Žičah, najbrž niso bili kopirani za potrebe tega, pač pa drugih kartuzijanskih samostanov, saj žiška skupnost ni potrebovala toliko antifonalov. Podobno je mogoče soditi o psalterju NUK, Ms 21, ki je nastal v Žičah, vendar se je ohranil preko pleterske knjižnice. Najstarejši žiški gradual, po katerem je v Žičah potekalo mašno bogoslužje, je iz 14. stol. in možno je, da je bil ta rokopis tudi predloga drugemu, mlajšemu žiškemu gradualu.

Na Slovenskem so obstajale kar štiri kartuzije in od teh ima poleg Žič starejšo glasbeno zapuščino še Bistra, od koder zelo verjetno izhaja gradual NUK, Ms 22. Zdi se, da so menihi, ki so okoli leta 1260 naselili Bistro in prišli tja domnevno iz Italije, prinesli s sabo tudi ta rokopis. To je razvidno iz dejstva, da bistrski gradual prvotno ni imel praznika oglejskih mučencev Mohorja in Fortunata; ta praznik je bil z ozirom na to, da je bil samostan na področju oglejskega patriarhata, vnesen v rokopis šele kasneje. ${ }^{74}$ Po tem rokopisu so morali bistrski kartuzijani opravljati mašo več stoletij, saj kažejo listi rokopisa sledove dolgotrajne rabe. Iz Bistre izvira tudi besedilo o recitacijskih formulah, ki je sicer zasnovano kot teoretični traktat, vendar bi moglo biti uporabno pri glasbenem podajanju nekaterih liturgičnih besedil. Poleg maše so bistrski kartuzijani opravljali tudi peti oficij, a o ustreznem antifonalu ni sledu.

V času pred 15. stol. je na Slovenskem obstajala še cela vrsta drugih samostanov. Pomembnejši med njimi so bili benediktinski v Gornjem gradu, cistercijanski v Kostanjevici, kartuzijanska v Jurkloštru in Pleterjah. ${ }^{75}$ Koralni rokopisi teh ustanov z izjemo pleterskega psalterja in jurklošterskega antifonala niso znani. Za gornjegrajski samostan je mogoče domnevati, da so bili njegovi rokopisi odtujeni in pogubljeni ob njegovi razpustitvi. Ob ustanovitvi ljubljanske škofije je bil namreč ta samostan dodeljen njej, vendar se menihi s to odločitvijo niso hoteli sprijazniti, zaradi česar je bil samostan leta 1474 ukinjen. ${ }^{76}$

Nekaj več kot za čas od 12. do 14. stol. je mogoče reči za 15. in 16. stol., kar velja zlasti za svetne ustanove. Še preden je bila v Ljubljani pri cerkvi sv. Nikolaja, podružnici župnije sv. Petra, ustanovljena škofija, je tu obstajala šola, katere gojenci so se nedvomno ukvarjali tudi s petjem, in sicer z liturgičnim enoglasjem. Da so gojenci v resnici prepevali koral, je razvidno iz ustreznih določil v tistih ustanovnih listinah, ki omenjajo

${ }^{72}$ J. Höfler, Tokovi glasbene kulture na Slovenskem, str. 12; J. Snoj, Srednjeveški glasbeni kodeksi, str. 51-53 (tu tudi faksimile).

${ }^{73}$ R. Flotzinger, Die notierten mittelalterlichen Handschriften aus der Kartause Seiz, str. 56.

${ }^{74}$ J. Snoj, Graduals from the Charterhouses Žiče (Seiz) and Bistra (Freudenthal), str. 581-582.

${ }^{75}$ F. M. Dolinar, Svetne in redovne kleriške skupnosti v srednjem veku na Slovenskem, str. 30-32.

${ }^{76}$ Nav. delo, str. 31. 
učitelja in učence. ${ }^{77}$ Kako je izgledal pouk glasbe, kakšno je bilo morebitno sodelovanje gojencev pri bogoslužju, o vsem tem je težko reči kaj določnega. Potem, ko je bila v letih 1461-1462 pri cerkvi sv. Nikolaja ustanovljena škofija s kapitljem, je tu gotovo obstajalo stalno, vsakodnevno peto oficijsko in mašno bogoslužje. V ustanovni listini škofije je jasno zapisano, naj kanoniki, 10 po številu, opravljajo peti oficij, in sicer po obrednem redu oglejske cerkve. ${ }^{78}$ Ljubljanska škofija, ki je bila sprva zelo majhna, je bila sicer izločena iz oglejskega patriarhata, vendar je obdržala oglejski obrednik, ki je tu veljal že stoletja poprej. Kapiteljski protokoli za naslednja desetletja večkrat omenjajo liturgijo in natančneje določajo njen potek oz. posamičnosti v zvezi z njo. ${ }^{79}$ Liturgija je morala nedvomno potekati po ustreznih koralnih rokopisih. Obstajati sta morala vsaj antifonal ter gradual ljubljanske stolnice, vendar danes nista poznana. Domnevati je mogoče, da so bili stolnični liturgični rokopisi sredi 17. stol., ko je bil v času škofov Scarlichija in Rabatte oglejski obred zamenjan s tridentinskim, ${ }^{80}$ uničeni. Med foliji uničenih koralnih rokopisov, hranjenih v Ljubljani, je obsežnejši fragment dvodelnega antifonala ter z isto roko pisani fragment psalterja, ki bi tako po svoji starosti kot po liturgičnih značilnostih mogla biti ostanka v stolnici rabljenih glasbenih knjig. ${ }^{81}$

Tudi v sicer izgubljeni ustanovni listini novomeškega kapitlja je bilo določeno opravljanje petega bogoslužja. A tako kot v primeru ljubljanske stolnice lahko možne preostanke novomeških liturgičnih knjig iščemo le med ohranjenimi fragmenti. Morda je fragment nekega antifonala, katerega listi so se ohranili le na platnicah z Dolenjske izvirajočih knjig, preostanek rokopisa, po katerem se je opravljal oficij v novomeškem kapitlju. ${ }^{82}$

Več kot o ljubljanski škofiji in novomeškem kapitlju je mogoče reči o cerkvi sv. Kancijana v Kranju, središču kranjske župnije, ki v 15. stol. še ni bila del ljubljanske škofije. ${ }^{83}$ Kot je razvidno iz Santoninovega opisa iz leta 1486, so bile v kranjski župnijski cerkvi orgle, ki jih je dal postaviti takratni župnik Matthias Operta. Santonino omenja tudi petje in njegov sicer literarni opis dopušča domnevo, da je v kranjski cerkvi zvenelo večglasje ${ }^{84}$ Kranjsko župnišče je imelo razmeroma bogato knjižnico in v njej so bili vsaj trije z glasbenega stališča zanimivi kodeksi. Prvi je lekcionar iz 14. stol., ki vsebuje med drugim tudi vse štiri pasijone. Ti so $\mathrm{v}$ rokopisu opremljeni z znaki, ki določajo, kateri pevec naj poje kateri del besedila, mestoma pa tudi z glasbenim zapisom. Obstoj tega rokopisa nakazuje, da se je v Kranju v sklopu liturgije velikega tedna pel enoglasni koralni

\footnotetext{
77 J. Höfler, Glasba v poznosrednjeveških beneficijih na Slovenskem, str. 89-92.

${ }^{78}$ Gl. ustrezno mesto v že omenjeni ustanovni listini: L. Žnidaršič Golec, nav. delo, str. 309.

${ }^{79}$ Gl. op. 44.

${ }^{80}$ France Ušeničnik, Obrednik oglejske cerkve v ljubljanski škofiji, Bogoslovni vestnik 4 (1924), str. 119-121.

${ }^{81}$ Jurij Snoj, Fragmenti srednjeveških glasbenih rokopisov s poznogotsko notacijo v Ljubljani, Univerza v Ljubljani, Filozofska fakulteta, 1987 (doktorsko delo), »Fragment 65«, »Fragment 66《, »Fragment 67《.

82 J. Snoj, nav. delo, »Fragment $63 \ll$.

${ }^{83}$ Prvotni obseg ljubljanske škofije je podan v delu: J. Mlinarič, Cerkev na Slovenskem v srednjem veku, str. 74.

${ }^{84} \gg$... missam ... audivimus, quam organa et suavissime cantorum voces iucundiorem prebuere ...« G. Vale, nav. delo, str. 183, 184.
} 
pasijon. ${ }^{85}$ Nadalje se je v Kranju ohranil že omenjeni zapis triglasnega glasbenega obrazca za petje jutranjičnih lekcij. Zapis na prvi strani sicer neglasbenega kodeksa izvira iz 15 . stol.; ali je nastal v Kranju ali kje drugje, ni razvidno.

Bolj razločno kot ta dva je s kranjsko cerkvijo povezan tretji glasbeno zanimivi kodeks nekdanje župnijske knjižnice, že omenjeni dvodelni antifonal. Liturgični red tega, zelo verjetno za cerkev sv. Kancijana nastalega rokopisa, ni strogo oglejski v tem smislu, da bi se razpored spevov v njem povsem ujemal z onim v oglejskih rokopisih in tiskih, kot je npr. tiskani oglejski brevir iz leta $1496 .{ }^{86}$ Nedvomno pa je oglejski v tem, da vsebuje verzificirane oficije za nekatere pomembnejše oglejske svetnike. Ti so: 1. Helarij in Tacijan, 2. Kancij, Kancijan, Kancijanila in Prot, 3. Mohor in Fortunat, 4. Evfemija, Doroteja, Tekla in Erazma. Rokopis je kompiliral Ioannes von Werd de Augusta, ki je bil torej doma iz Donauwörtha ${ }^{87} \mathrm{v}$ bližini Augsburga na Bavarskem. Ioannes je nedvomno kompiliral besedila, glasbeni zapis pa je morda njegovo ali pa delo katerega od njegovih pomočnikov. Pri kompiliranju kranjskega rokopisa so pisci morali imeti pred sabo več predlog, med katerimi so bili tudi oglejski antifonali, iz katerih so prevzeli verzificirane oficije za oglejske svetnike. Vendar pa enega od verzificiranih oficijev kranjskega antifonala $\mathrm{v}$ oglejskih kodeksih ni: to je oficij za praznik patrona kranjske župnijske cerkve sv. Kancijana, točneje verzificirani oficij za pravkar omenjeno skupino mučencev Kancijev. Ta oficij, ta pesniška in glasbena stvaritev je po današnjem vedenju ohranjena le v kranjskem rokopisu. Iz tega je mogoče sklepati, da je kranjski antifonal nastal prav za cerkev v Kranju, morda po naročilu župnika Operte, in da je bil hkrati z novim rokopisom spesnjem in uglasben tudi nov verzificirani oficij v čast njenim patronom. ${ }^{88}$ Vse to se dobro ujema s siceršnjimi dejavnostmi kranjske župnije: približno v istem času je bila cerkev sv. Kancijana obnovljena, nekaj kasneje pa je naročila nov krilni oltar, ki je med drugim prikazoval mučeništvo Kancijev, o katerem govori tudi pesniško oblikovano besedilo oficija. ${ }^{89}$

Od svetnih ustanov imata ohranjene glasbene rokopise še škofija v Kopru ter kapitelj v Izoli. Kot je bilo omenjeno, je v Kopru obstajala škofija že v zgodnjem srednjem veku, vendar je ponovna, nepretrgana vrsta koprskih škofov izpričana šele za čas po 12. stol. To daje vtis, da je bila koprska škofija po nekajstoletnem zamrtju v 12. stol. obnovljena. ${ }^{90}$ Hipotetično je sicer mogoče predpostaviti, da je v Kopru koralno peto bogoslužje obstajalo že v 12. stol., a ohranjeni rokopisi koprske stolnice so mlajši. Dvodelni gradual je

\footnotetext{
${ }^{85}$ NŠAL, Rkp 5. J. Snoj, Srednjeveški glasbeni kodeksi, str. 29-31 (tu tudi faksimile).

${ }^{86}$ Breviarium Aquileiense, Benetke 1496 (izvoda v NUK, 13814 in 14 425).

${ }^{87}$ Staro ime za ta kraj je Werd.

${ }^{88}$ Jurij Snoj, Historia Cantiorum in the Antiphonary from Kranj, Cantus Planus. Papers read at the $9^{\text {th }}$ meeting, Esztergom \& Visegrád, 1998, ur. László Dobszay, Budapest, Hungarian Academy of Sciences, Institute for Musicology, 2001, str. 254-257; Jurij Snoj, Pesniški oficij Kancijev v antifonalu iz Kranja, Zbornik ob jubileju Jožeta Sivca, ur. Jurij Snoj in Darja Frelih, Ljubljana, Založba ZRC, 2000, str. 45-50. Obstoji znanstvenokritična izdaja tega oficija: Jurij Snoj, Two Aquileian poetic offices, Musicological Studies 65/8, Ottawa, The Institute of Medaeval Music, 2003.

${ }^{89}$ Enciklopedija Slovenije 5, Ljubljana, Mladinska knjiga, 1991, str. 385, 395.

${ }^{90}$ Darko Darovec, Koprska škofija in Slovani od srednjega do novega veka, Acta Histriae 9/1 (2001), str. $83-85$.
} 
iz 14. stol., prvotno šestdelni, zdaj petdelni antifonal pa iz 15. stol. Sam gradual je delo več piscev in isto velja tudi za antifonal. S tem dajejo koprski rokopisi vtis, da niso bili pridobljeni naenkrat, pač pa postopoma, tako da je bil celotni komplet za peto liturgijo potrebnih rokopisov v stolnici prisoten šele sredi 15. stol. Zanimivo je tole: koprska škofija je bila del oglejskega patriarhata in koprski škof je bil oglejski sufragan. ${ }^{91}$ Kljub temu pa koprski rokopisi ne sledijo oglejskemu liturgičnemu redu, kar je med drugim razvidno tudi iz tega, da v sanktoralu ne navajajo niti enega od tipičnih oglejskih svetnikov. ${ }^{92}$ Zelo verjetno so bili - z izjemo enega - izdelani oz. nabavljeni v več različnih neoglejskih skriptorijih, ${ }^{93}$ in sicer kot rokopisi brez kakih za bodoče mesto uporabe značilnih sestavin, se pravi kot rokopisi, ki bi se lahko rabili kjer koli. V Kopru je nedvomno nastal le eden. Kot je razvidno iz eksplicita, je tisti del antifonala, ki vsebuje skupne svetniške oficije, kopiral »Nazarius de Iustinopoli«, se pravi 'Nazarij iz Kopra'. Morda je ta Nazarij oseba, ki si je leta 1431 pri čedadskem kapitlju izposodila rokopis, in morda je bil ta rokopis prav tisti, po katerem je nastal Nazarijev kodeks. ${ }^{94}$ Ne oziraje se na verjetnost te podmene je gotovo, da se je v Kopru v 15. stol. zapisovala in kopirala glasba.

V svoji prvotni obliki ne vsebujejo koprski kodeksi nič takega, kar bi jih vezalo na kraj uporabe, Koper. Vendar ima Nazarijev antifonal kasnejši dodatek, ki sicer ni delo Nazarijeve roke, je pa izključno koprski: oficij za god prvega koprskega škofa in mestnega zavetnika sv. Nazarija. Ob koncu rokopisa sta dve verziji omenjene stvaritve: krajša, ki je starejša, in obsežnejša mlajša. Zapis starejše sodi po paleografskih značilnostih sodeč še v tradicijo srednjeveškega pismenstva, medtem ko je zapis mlajše verzije delo pisca 16 . ali celo 17. stol. Z veliko mero gotovosti je mogoče reči, da je to pesniško in glasbeno delo nastalo v Kopru, in sicer za liturgijo koprske stolnice. Verjetno je bila najprej spesnjena krajša vezija, ki je bila kasneje predelana v popoln oficij. Nazarijev oficij priča, da je na pragu novega veka obstajala $v$ Kopru literarna in glasbena tvornost. ${ }^{95}$

$\mathrm{Z}$ beneške obale se je ohranil tudi štiridelni antifonal. Bil je v rabi izolskega kapitlja, ki je od poznega srednjega veka dalje obstajal pri cerkvi sv. Mavra. ${ }^{96}$ Po paleografskih značilnostih sodeč so izolski rokopisi iz 15. stol.; z glasbenozgodovinskega stališča doslej še niso bili natančneje pregledani.

V tistih že omenjenih samostanih, ki imajo glasbene rokopise izpred 15. stol. (Stična, Žiče, Bistra), se je v 15. in 16. stol. nadaljevalo takrat že več stoletij staro izročilo. V Žičah je v tem času mogoče opaziti povečano produkcijo novih glasbenih kodeksov, saj jih je med znanimi kar devet iz 15. stol. (gl. tabelo 2). A poleg teh imajo za 15. stol. izpričano liturgično enoglasje še nekateri drugi samostani. Ustanovne listine, kolikor so poznane, omenjajo kot mesta s peto liturgijo samostan mariborskih minoritov, maltezarjev v Meljah, križnikov v Ljubljani in Metliki, avguštincev v Ljubljani, samostan dominikank v Radljah ter samostana ljubljanskih in novomeških frančiškanov. ${ }^{97}$ Iz slednjih dveh samostanov,

${ }^{91}$ J. Mlinarič, Cerkev na Slovenskem v srednjem veku, str. 62.

92 J. Snoj, Koralni kodeksi koprske stolnice, str. 130-133.

${ }^{93}$ Nav. delo, str. 135.

${ }^{94} \mathrm{Nav}$ delo, str. $135-136$.

${ }^{95}$ J. Snoj, nav. delo, str. 136-137 (tu tudi faksimile).

${ }^{96}$ J. Mlinarič, Cerkev na Slovenskem v srednjem veku, str. 84.

${ }^{97} \mathrm{~J}$. Snoj, Zgodovinski viri o glasbenem življenju na Slovenskem do konca srednjega veka, str. 115. 
tj. ljubljanskega in novomeškega frančiškanskega samostana, so se ohranili tudi sami koralni rokopisi.

Zanimiv primer predstavljata graduala iz novomeškega frančiškanskega samostana. Ta dva rokopisa, ki sta si po vsebini zelo podobna, sta z ozirom na liturgični red nedvomno kartuzijanska, ${ }^{98}$ ne frančiškanska, in morda sta bila kopirana v Žičah. Glede uporabe liturgičnih knjig srednjeveške skupnosti niso bile vedno toge in možno je, da so novomeški frančiškani, ki so se pri cerkvi sv. Lenarta naselili leta $1472,{ }^{99}$ opravljali mašo po kartuzijanskem obredu.

Drugače je bilo v Ljubljani. Leta 1491 so ljubljanski frančiškanski samostan prevzeli observantje in nekaj kasneje je bila tu ustanovljena samostojna nova kustodija. ${ }^{100}$ Morda so bili prav ob tej priložnosti oskrbljeni novi rokopisi, po katerih naj bi potekalo samostansko bogoslužje. Ti rokopisi, ki so nastali konec 15. ali pa že na začetku 16. stol., so po svoji vsebini, po svojem liturgičnem redu frančiškanski. ${ }^{101}$ Po njih se je v ljubljanskem samostanu pelo več stoletij.

Če si ob koncu tega pregleda prikličemo v zavest vse ustanove, kjer je izpričano obstajal gregorijanski koral oz. liturgično enoglasje, bodisi svetne (Koper: stolnica, Izola: kapitelj, Ljubljana: stolnica, Novo mesto: kapitelj, Kranj: župnija itd.) bodisi samostanske (cisterca Stična, kartuzije Žiče, Jurklošter, Pleterje, Bistra, frančiškanska samostana v Novem mestu in Ljubljani itd.), vidimo, da njihovo število ni bilo majhno. Mreža na Slovenskem obstoječih ustanov z liturgičnim enoglasjem je bila razmeroma gosta in z ozirom na liturgično in glasbeno raznolikost tudi pestra.

\section{Možnosti prihodnjega študija}

Kot je razvidno iz doslejšnjega prikaza, je glasba različnih zvrsti, ki so obstajale v srednjem veku na Slovenskem, le sestavni del širših evropskih glasbenih tokov. Zaradi tega je ni mogoče obravnavati in preučevati izolirano, ločeno, pač pa v ustreznih sklopih. Ohranjeni drobci polifone umetnosti, ki so si med sabo zelo različni, so tako predstavniki treh različnih smeri oz. plasti v srednjeveškem večglasju: nemenzuriranega večglasja, italijanske polifonije ter franko-flamske polifonije v srednji Evropi. Štajerski pesniki sodijo v kompleks nemškega minnesanga, glagoljaši v sklop srednjeveškega glagoljaštva. Podobno je potrebno v ustreznih okvirih obravnavati tudi srednjeveško liturgično enoglasje na Slovenskem: cistercijanski rokopis sodi v sklop razprave o cistercijanski liturgiji in glasbi, kartuzijanski rokopisi v zgodovino liturgične glasbe srednjeveških kartuzijanov, frančiškanski v sklop liturgične glasbe srednjeveških frančiškanov, liturgično enoglasje

${ }^{98}$ To je na prvi pogled razvidno iz serije aleluj za pobinkoštne nedelje, ki je ista kot v kartuzijanskem gradualu NUK, Ms 22.

99 J. Mlinarič, nav. delo, str. 81.

${ }^{100}$ Guido Rant, Die Franziskaner der österreichischen Provinz, ihr Wirken in Nieder-Österreich, Steiermark und Krain, Kamnik, 1908, str. 63-65; Jože Škofljanec, Red manjših bratov in Provinca sv. Križa, Frančiškani v Ljubljani, ur. Silvin Krajnc, Ljubljana, Samostan in župnija Marijinega oznanjenja, 2000, str. 35.

${ }^{101}$ J. Snoj, The Franciscns in Carniola and their Chant (v tisku). 
svetnih cerkva pa v sklop zgodovine gregorijanskega korala v srednji Evropi oz. v oglejskem patriarhatu in salzburški škofiji. A prav zaradi prikazane vezanosti so možnosti študija in spoznavanja na Slovenskem obstoječe glasbe odvisne od splošne stopnje poznavanja glasbenih tokov, ki jim pripadajo. Kako daleč je mogoče prodreti v žiške rokopise, je npr. v veliki meri odvisno od poznavanja srednjeveškega kartuzijanskega rokopisja sploh.

Od glasbenih zvrsti, ki so v srednjem veku obstajale na Slovenskem, je daleč najpomembnejše liturgično enoglasje. Nadaljnje raziskovanje tega področja more potekati iz dveh različnih, vendar v zgodovinskih sintezah dopolnjujočih se izhodišč: prvo je natančnejši študij na Slovenskem uporabljanih glasbenih kodeksov, drugo pa ustrezni študij zgodovine posamičnih ustanov, kjer je peto koralno bogoslužje dejansko obstajalo.

V zvezi s študijem rokopisov je treba poudariti, da je iz njih samih le redko razvidno, kje je bil kateri v rabi in kje je nastal, in toliko manj je mesto izvora in uporabe razvidno v primeru fragmentov. Ko gre za spomenike srednjeveške umetnosti, je ugotavljanje izvora pogosteje cilj kot pa izhodišče raziskave. Prav zaradi tega je smiselno, da se študijsko preučujejo vsi na Slovenskem ohranjeni spomeniki srednjeveškega enoglasja ne glede na to, koliko so popolni, in ne glede na to, ali so avtohtoni ali pa se tu hranijo le slučajno. Ob tem je razumljivo, da zahteva fragmentarno gradivo, se pravi naključno ohranjeni listi iz uničenih rokopisov, drugačen pristop kot celi kodeksi. Rokopise, ki so jim preostali fragmenti nekdaj pripadali, je potrebno rekonstruirati. To pomeni: v množici najdenih in zajetih folijev je treba prepoznati tiste, ki izhajajo iz istih, nekdaj popolnih, kasneje pa uničenih knjig. Predvideti je treba mesta, ki so jih v uničenih rokopisih imeli, in o teh si je potrebno na osnovi tovrstnih rekonstrukcij ustvariti kar najbolj popolno predstavo. Šele ko je vse to opravljeno, je v tem smislu rekonstruirane rokopise mogoče postaviti ob bok tistim, ki so v celoti ohranjeni.

Pred časom so bile z namenom, najti vse srednjeveške fragmente z glasbenim zapisom, natančno pregledane vse ljubljanske knjižnice in arhivi. Najdeno je bilo ustrezno popisano in fotografirano. To delo bi se lahko nadaljevalo, in sicer v smislu trojne širitve: 1 . Koralni rokopisi so hkrati tudi liturgični rokopisi in marsikatero vprašanje v zvezi z njimi je hkrati tudi liturgičnozgodovinsko vprašanje. Smiselno bi bilo, da bi se obenem z glasbenimi iskali in popisovali tudi fragmenti uničenih liturgičnih rokopisov brez glasbenega zapisa (fragmenti brevirjev, misalov, lekcionarjev itd.). Katalog fragmentov z glasbenim zapisom bi bil tako razširjen s katalogom fragmentov, ki vsebujejo petju namenjena besedila, vendar brez glasbenega zapisa. S tem bi bilo popisano domala vse srednjeveško fragmentarno rokopisje na Slovenskem, saj so fragmenti z drugimi vsebinami v slovenskih kot tudi drugih knjižnicah zelo redki. Študij liturgičnih rokopisov oz. njihovih fragmentov bi omogočal zanesljivejše reševanje zgodovinskih vprašanj v zvezi s koralnimi rokopisi. 2. Iskanje in popisovanje fragmentov srednjeveških rokopisov bi bilo treba razširiti na druga slovenska mesta. V poštev pridejo vse tiste knjižnice in arhivi, ki imajo gradivo izpred sredine 18. stol. Kolikor te ustanove še nimajo ustreznih seznamov, bi bilo potrebno natančno prečesati vse njihove knjižne oz. arhivske fonde do omenjenega časa. Ker so pergamentni foliji ali odrezki iz uničenih kodeksov v knjižnih vezavah pogosto skriti, bi bilo treba iti od knjižne police do knjižne police oz. od fascikla do fascikla in pregledati vsako, do sredine 18. stol. nastalo vezavo. Vse najdeno bi bilo treba ustrezno popisati in fotografirati. 3. Za vse popisane fragmente bi bilo potrebno izdelati ustrezne vsebinske 
indekse, iz katerih bi bilo razvidno, katere vsebinske enote - speve - dejansko vsebujejo. Vse to bi omogočilo rekonstrukcijo uničenih rokopisov do mere, ki bi jo dopuščal obseg ohranjenega. S tem bi bilo fragmentarno gradivo pripravljeno za nadaljnji študij.

V celoti ohranjeni rokopisi narekujejo drugačen pristop. Rekonstrukcijska dela tu niso potrebna, vendar je ob osnovnem kodikološkem opisu za vsakega od njih potrebno izdelati indeks. Srednjeveški gradual vsebuje nekaj sto, antifonal pa nekaj tisoč spevov in v vsakem rokopisu so ti razporejeni nekoliko drugače. Strokovna obravnava katerega koli srednjeveškega koralnega ali liturgičnega kodeksa ni možna brez natančnega poznavanja njegove vsebine oz. brez možnosti dostopa do nje. Dostop do vsebine rokopisa omogočajo ustrezni indeksi. Doslej je bil v podatkovno bazo, namenjeno vsebinam srednjeveških antifonalov, vključen le antifonal iz Kranja. ${ }^{102}$ Indekse, kakršen je bil izdelan za ta rokopis, bi potrebovali tudi ostali na Slovenskem hranjeni koralni rokopisi.

Drugo izhodišče za spoznavanje koralne zgodovine na Slovenskem je študij zgodovine ustanov, kjer je obstajalo koralno bogoslužje. Sem sodijo samostani, ljubljanska in koprska škofija, novomeški, izolski in piranski kapitelj, nenazadnje pa tudi župnije, predvsem mestne. Mnoge od omenjenih ustanov, zlasti samostanske, so že bile deležne natančnejših zgodovinskih prikazov, ki bodo v izdatno pomoč raziskovalcem njihove liturgije. Vendar bi bilo za poznavanje njihove liturgične in glasbene zgodovine potrebno ohranjene zgodovinske vire preučiti posebej z ozirom na njihovo liturgično in glasbeno vsebino. V strokovni glasbenozgodovinski literaturi se pogosto omenjajo posamični glasbeno zanimivi drobci iz zgodovine raznih ustanov, a tematsko osrediščeni prikazi liturgičnega in glasbenega življenja posamičnih srednjeveških liturgičnih skupnosti na Slovenskem doslej še niso bili narejeni. Eden od razlogov za to je zelo verjetno dejstvo, da je ustrezno gradivo raztreseno in pičlo, zaradi česar na prvi pogled ne obeta veliko. Študij liturgične in glasbene zgodovine posamičnih na Slovenskem obstoječih liturgičnih skupnosti vključuje tudi iskanje njihovih v celoti ali fragmentarno ohranjenih rokopisov bodisi na Slovenskem bodisi drugje.

Kot je bilo že omenjeno, je poznavanje vsega tistega, kar je obstajalo na Slovenskem, v veliki meri odvisno od splošnega vedenja o srednjeveškem koralnem rokopisju in njegovi zgodovini. To velja za liturgično in glasbeno zgodovino na Slovenskem obstoječih liturgičnih ustanov, za tu hranjene rokopise, še zlasti pa za fragmente. Le natančno poznavanje sorodnega fragmentarnega gradiva v drugih hraniščih, hkrati pa tudi natančno poznavanje topografije srednjeveških skriptorijev ter značilnosti v njih nastalih kodeksov bi lahko razkrilo izvor tistih uničenih rokopisov, o katerih obstoju pričajo na Slovenskem ohranjeni foliji.

Delo s fragmenti, osnovni študij v celoti ohranjenih rokopisov, branje zgodovinskih virov, vse to odpira raziskovalcu vrsto vnaprej težko predvidljivih pogledov. Ti lahko postanejo teme razprav z najrazličnejšimi, tudi tu podane okvire presegajočimi vsebinami.

${ }^{102}$ Cantus: A Database for Latin Ecclesiastical Chant, ur. Debra Lacoste. 


\section{GENRES OF MUSIC IN SLOVENIA IN THE MIDDLE AGES}

\section{Summary}

The music that was present in Slovenian ethnic territory in the Middle Ages cannot be referred to merely as "medieval music"; as indicated by both direct and indirect sources, several more-or-less independent genres of music existed in this territory in the Middle Ages (see abstract). These belonged to broader European medieval cultural currents, and must therefore be studied in accordance with this important fact.

Vernacular singing, or music in the oral tradition of the Slovenian-, German-, or Italian-speaking populations, is confirmed for the most part by incidental sporadic remarks in the writings of medieval authors as well as by some preserved texts (without music). The presence of Glagolitic chant may be inferred from the fact that there were communities that celebrated the liturgy in Old Church Slavic (e.g., the monastery of the Tertiary friars in Koper). The presence of Minnesang may be surmised based on the fact that three of the poets included in the Codex Manesse came from southern Styria. However, the melodies of their preserved poems were very likely never written down. The sporadic remnants of medieval polyphony found in Slovenian libraries belong to various stylistic layers of polyphonic music and cannot be interpreted as relating to one and the same tradition. The existence of polyphonic singing can also be conjectured on the basis of literary reports.

Of all the genres of music that existed in Slovenian regions, only liturgical monody can be studied on the basis of preserved music manuscripts. In Slovenian libraries there are twenty-three music codices (see Table 1); in addition to these, several hundred one- or two-folio fragments of destroyed music manuscripts have been discovered and described. Some music manuscripts that were in use in ethnically Slovenian regions are preserved elsewhere: fourteen music manuscripts that are today mostly kept in Graz originated at the Carthusian monastery in Žiče (Germ. Seitz) in southern Styria (see Table 2), and another one from the Carthusian monastery in Jurklošter (Germ. Gairach; also currently held in Graz). The monastic manuscripts are written in square or Cistercian notation; those of secular churches are either in square notation (in the coastal, historically Venetian areas) or one specific type of Gothic notation (in the province of Carniola). Among the preserved fragments whose origin and place of use are difficult to define, there are several written in German adiastematic neumes. In addition to being preserved in the manuscripts, liturgical chanting is mentioned in several historical documents; taking into consideration both historical documents as well as the preserved manuscripts, a rather dense web of institutions (churches) practicing sung liturgy in Slovenian ethnic territory can be identified. However, the liturgical singing of these churches did not belong to just one tradition. All the preserved manuscripts or fragments must therefore be studied in their proper historical contexts: those from the monasteries in the context of the liturgy of the appropriate monastic order, and those from the secular churches in the context of the liturgy and music of the appropriate metropolitan church (Aquileia or Salzburg). 